Itinera Spiritualia

$\mathrm{XI} \cdot 2018 \cdot 93-135$

\title{
KU FILOZOFII PRZYJAŹNI. W DIALOGU Z PLATONEM, ARYSTOTELESEM I ŚW. TERESĄ OD JEZUSA (CZĘŚĆ III)
}

\section{Od Pierwszego Przyjaciela do wielu przyjació}

Niniejsza druga częśc trzeciego rozdziału szerszej pracy poświęconej filozofii przyjaźni rozwija dalsze wątki etyki przyjaźni w ujęciu Arystotelesa i św. Teresy od Jezusa. Po ukazaniu w pierwszej jego części $i^{1}$ metafizycznych podstaw etyki przyjaźni w myśli obojga Mistrzów (3.1), zwróceniu uwagi na egzystencjalną potrzebę przyjaźni i przyjaciół (3.2) oraz omówieniu warunków i cech przyjaźni (3.3), poniżej zostaną podjęte kolejne cztery ważne zagadnienia etyczne. Najpierw przedstawimy podstawowe formy przyjaźni (3.4) - trzy według Arystotelesa i dwie według św. Teresy. Następnie zagadnienie przyjaźni zostanie zbadane w dwóch istotnych i konstytuujących ją aspektach, które czasami błędnie uchodzą za sprzeczne ze sobą: w pierwszej kolejności przeanalizujemy przyjaźń jako cnotę (3.5), w drugiej - przyjaźń jako uczucie (3.6). Na koniec przebadamy pasjonujący temat relacji zachodzącej między przyjaźnią a miłością (3.7), co pozwoli nam jeszcze precyzyjniej określić, czym jest przyjaźń.

\subsection{Formy przyjaźni według Arystotelesa i św. Teresy od Jezusa}

Obecnym naszym celem jest opisanie najbardziej typowych form przyjaźni, tak jak zostały one zidentyfikowane przez Arystotelesa i św. Teresę i jak jawią się naszej świadomości i świadomości ogółu ludzi. Tego rodzaju fenomenologiczny opis nie jest czystą deskrypcją. Pomaga nam odróżnić p r zy ja źń a u ten ty cz ną od przyjaźni nieautentycznych. W tym sensie ma ogromne znaczenie egzystencjalne. W istocie,

1 Zob. „Itinera Spiritualia” X (2017), s. 163-194 (przyp. red.). 
nie wszystkie formy przyjaźni zdają się zasługiwać na to miano. Przekonujemy się o tym szczególnie w momencie kryzysu tej relacji. Odkrywamy wówczas, że prawdziwa przyjaźń nie jest łatwa, a związki, które początkowo określaliśmy tym mianem, okazują się często kruche, zawodne i niosące rozczarowanie. W związku z tym rodzą się w nas pytania: Dlaczego jestem zawiedziony przyjacielem lub on mną? Dlaczego pewne przyjaźnie nie wytrzymują próby czasu? Skąd mogę wiedzieć, czy więź, jaka mnie łączy z moim przyjacielem, jest rzeczywiście trwała i autentyczna? ${ }^{2}$ Poniższe refleksje są próbą pierwszej odpowiedzi na te i podobne pytania.

\subsubsection{Trzy typy przyjaźni według Arystotelesa}

Najcenniejszym wkładem Arystotelesa w zgłębienie zagadnienia przyjaźni jest rozróżnienie jej trzech typów: przyjaźni u tylitarnej, hedonicznej i cnotl i w ej. Filozof nadaje im to miano ze względu na trzy odmienne perspektywy bądź przedmioty, ku którym kierują się nasze uczucia, albo ze względu na trzy różne motywacje lub powody, jakie towarzyszą zawiązywaniu przyjaźni. Chodzi mianowicie o korzyść, przyjemność i dobro: „nie wszystko bywa, jak się wydaje, przedmiotem uczuć [dodatnich], lecz tylko to, co jest ich godne, a tym jest: to, co dobre, co przyjemne i co pożyteczne" ${ }^{3}$.

Skoro są trzy przedmioty, do k tórych się dąży, trzy są również typy przyjaźni: „Trzy tedy są rodzaje przyjaźni, równe liczbą tym rzeczom, które zasługują na uczucia dodatnie $[\ldots]$. Ci, co nawzajem są sobie przyjaciółmi, życzą sobie nawzajem dobrze i czynią to ze względu na to, co jest powodem ich przyjaźni".

Po ogólnym uzasadnieniu rozróżnienia typów przyjaźni Arystoteles przechodzi do nakreślenia obrazu każdego z nich. Najpierw charakteryzuje łącznie dwa pierwsze typy, czyli utylitarny i hedoniczny:

Ludzie więc, którzy są sobie nawzajem przyjaciółmi gwoli wynikającej stąd dla nich korzyści, nie żywią dla siebie uczuć przyjaznych ze względu na osobę przyjaciela, lecz tylko o tyle, o ile dla każdego z nich wynika stąd jakieś dobro. Podobnie ma się rzecz z tymi, którzy są sobie przyjaciółmi ze względu na wynikającą stąd dla nich przyjemność; nie za to bowiem lubią [na przykład] ludzi gładkich i dowcipnych, że ci posiadają pewne cechy charakteru, lecz za to, że sprawiają im przyjemność. Ci zatem, co są sobie przyjaciółmi dla korzyści, kochają się nawzajem ze względu na własne swe dobro, a ci, którzy są przyjaciółmi dla przyjemności, kochają ze względu na to, co dla nich samych jest przyjemne, a nie ze względu na to, że osoba kochana jest tym, kim jest, lecz o tyle, o ile jest pożyteczna czy

2 Por. J. Vanier, Il sapore della felicità. Alle basi della morale con Aristotele, Bologna 2001, s. 56.

3 Etyka nikomachejska, VIII, 2, 1155 b 18. Cytaty z Arystotelesa za: Dzieła wszystkie, t. I-VII, Warszawa 1990-2003. 
miła. Te więc stosunki przyjacielskie są przypadkowe; osobnik bowiem kochany jest tu kochany nie ze względu na to, że jest tym, kim jest, lecz ze względu na to, że bądź przysparza jakiegoś dobra, bądź sprawia przyjemność. Toteż przyjaźnie tego rodzaju łatwo ulegają zerwaniu, jeśli ludzie, między którymi zachodzą, nie pozostają takimi samymi, jak byli, bo gdy przestają być przyjemni lub pożyteczni, to tracą miłość ${ }^{4}$.

Następnie szkicuje obraz przyjaźni opartej na cnocie:

Doskonałą formą przyjaźni jest przyjaźń między ludźmi etycznie dzielnymi [cnotliwymi] i podobnymi do siebie w dzielności [cnocie] etycznej. W podobny bowiem sposób nawzajem sobie dobrze życzą, jako ludzie etycznie dzielni [ cnotliwi], a są nimi sami w sobie; owóż ci, którzy dobrze życzą swym przyjaciołom ze względu na nich samych, są przyjaciółmi w najwłaściwszym tego słowa znaczeniu (jako że w ten sposób ustosunkowują się do swych przyjaciół ze względu na ich naturę, a nie ze względów ubocznych); przyjaźń ich więc trwa dopóty, dopóki są etycznie dzielni [cnotliwi], a dzielność [cnota] etyczna jest czymś trwałym ${ }^{5}$.

Pomiędzy dwoma pierwszymi typami przyjaźni, zawieranymi ze względu na korzyść i przyjemność, a typem trzecim, opartym na dobru i cnocie, zachodzi różnica jakościowa. Faktycznie, nie stanowią one trzech gatunków jednego rodzaju, lecz pozostają do siebie raczej w relacji an a logicznej, a punktem odniesienia dla wszystkich jest przyjaźń oparta na cnocie (arete). Ta ostatnia w Etyce eudemejskiej nazwana jest wręcz „pierwszą przyjaźnią” (prote philia) ${ }^{6}$, w oczywistym nawiązaniu do Platońskiej idei „pierwszego przyjaciela” (proton philon) z Lizysa ${ }^{7}$. W ten sposób nie tylko Platon, ale również Arystoteles daje do zrozumienia, że jedynie ta prymarna przyjaźn jest przyjaźnią w pełnym tego słowa znaczeniu $(\text { kyriōs })^{8}$. Później, w Etyce nikomachejskiej, nazywa ja teleia philia, to znaczy przyjaźnią doskonałą , albo entelechia, czyli stanem ziszczenia, w którym „dochodzi do spełnienia to, co w pozostałych dwóch formach jest obecne jedynie w sposób jeszcze niedoskonały" ${ }^{10}$. Ale i te niedo-

4 Etyka nikomachejska, VIII, 3, 1156 a 5-20.

Tamże, VIII, 3, 1156 b $7-12$.

Etyka eudemejska, VII, 2, 1236 b 1.

Por. Platon, Lizys, 219 C-D. Cytaty z Platona za: Dialogi, t. I-II; Kęty 1999; Państwo. Prawa (VII ksiag), Kęty 1999. Zob. też w pierwszej części niniejszej pracy podrozdział 2.1.2. Platónska koncepcja "przyjaźni”, w którym na podstawie dialogu Lizys ukazana jest wędrówka filozofa od wielu przyjaciól do „Pierwszego Przyjaciela” ( „Itinera Spiritualia” IX [2016], s. 126-128). Por. G.H. Gadamer, Przyjażn i poznanie siebie. O roli przyjażni w greckiej etyce, w: tenże, Teoria, etyka edukacja. Eseje wybrane, Warszawa 2008, s. 148.

8 Etyka eudemejska, VII, 2, 1236 a 20.

9 Por. M. Smolak, Przyjaźn w świetle etyki Arystotelesa, Kraków 2013, s. 191-204; C. Danani, L'amicizia degli antichi. Gadamer in dialogo con Platone e Aristotele, Milano 2003, s. 256-257.

10 G. Pellegrini, Il bene e l'apparenza. Aristotele, l'amicizia e i limiti della morale, Roma 2008, s. 205. 
skonałe formy, chociaż nie są przyjaźniami w pełnym tego słowa znaczeniu, według Arystotelesa, będącego tu w polemice z Platonem, również zasługują na to miano ${ }^{11}$.

Nietrudno zauważyć, że właśnie te mniej wartościowe przyjaźnie mają się dzisiaj zupełnie nieźle. Przyjaźń utylitarna, mająca solidne wsparcie ideowe $\mathrm{w}$ filozofii utylitarystycznej, o czym pisałem na początku niniejszego rozdziału, zawiązywana jest przede wszystkim w przestrzeni publicznej państwa-miasta (polis). W ramach różnych zawodów, czy też interesów ekonomicznych lub politycznych, z partnerów handlowych tworzy ona tzw. przyjaciół biznesowych. Przyjaciele ci są wymienni, związki pomiędzy nimi - kruche i niepewne; wystarczy niewielka zmiana sytuacji społecznej, a przyjaźń natychmiast się załamuje. Najbardziej zaś wystawione na ryzyko i niebezpieczne są przyjaźnie polityczne. Służą one utrzymaniu władzy, rozwojowi interesów ekonomicznych albo po prostu realizacji własnych ambicji. Tylko szczęśliwy jakiś traf może sprawié, że nie kończą się dla kogoś szkodą albo że pozostają otwarte na inne osoby. Takie przyjaźnie, oparte na przemijalnych rzeczach i krótkowzrocznych wizjach, są w rzeczywistości powierzchowne i stanowią zawsze wyraz dobrze zakamuflowanego egoizmu ${ }^{12}$. Według Arystotelesa, są zwylle zawierane przez starszych ${ }^{13}$.

Przyjaźń hedoniczna natomiast, całkowicie usprawiedliwiona przez wspótczesną filozofię hedonistyczną ${ }^{14}$, jest $z$ kolei szczególnie atrakcyjna dla ludzi młodych - tak przynajmniej twierdził niegdyś Arystoteles ${ }^{15}$. Krzewi się ona w przestrzeniach, gdzie chętnie przebywają ze sobą, a więc raczej poza obowiązkową szkołą. Wspólne uprawianie sportu, spędzanie razem wolnego czasu, oddawanie się hobby albo jakiejś innej rozrywce są oczywiście same w sobie czynnościami dobrymi, ale jednocześnie stanowią idealną wylęgarnię związków płochych, nieprzemyślanych, zmiennych, tymczasowych, a w każdym razie pozbawionych większej głębi. Rzadko pojawia się

11 Etyka eudemejska, VII, 2, 1236 b 12-26.

12 Por. T. SöDING, L'amicizia con Gesiu, „Communio: Rivista Internazione di Teologia e Cultura” 2013, nr 237, s. 12.

13 Etyka nikomachejska, VIII, 3, 1156 a 23 nn.: „Tego rodzaju przyjaźń [dla korzyści] rodzi się najczęściej, jak się zdaje, między ludźmi starymi (jako że w podeszłym wieku ludzie nie szukają przyjemności, lecz korzyści). [...] Tacy przyjaciele wcale z sobą nie współżyją, a z czasem nawet nie są sobie nawzajem mili; nie odczuwają więc wcale braku wzajemnych z sobą stosunków, jeśli nie mają z siebie nawzajem żadnego pożytku; są sobie bowiem nawzajem o tyle tylko mili, o ile spodziewają się po sobie jakiejś korzyści".

14 Por. J. Galarowicz, Szczéscie na manowcach. Liberalizm - hedonizm - selfizm, Kęty 2017, s. 96-145.

15 Etyka nikomachejska, VIII, 3, 1156 a 32-b 3: „Przyjaźń ludzi młodych jest - jak się zdaje-podyktowana względem na przyjemność, bo kierują się oni w życiu namiętnościami i gonią przede wszystkim za tym, co im jest przyjemne i co chwila przynosi; ale wraz z postępującym wiekiem zmienią się teź przyjemności. Dlatego to ludzie młodzi szybko stają się przyjaciółmi i szybko przestają nimi być, wraz z tym bowiem, co przyjemne, ulega zmianie przyjaźń, tego zaś rodzaju przyjemności zmieniają się szybko. Młodzieńcy są też kochliwi; gdyż uczuciami miłosnymi rządzi przeważnie namiętność i żądza rozkoszy; dlatego zapłonąwszy miłością, ludzie młodzi szybko ostygają i często tego samego dnia zmieniają jej przedmiot". 
w nich pytanie o wyższe aspiracje drugiej osoby, nie wspominając już o pytaniu o cnotę. Jedynym spoiwem łączącym przyjaciół są te same upodobania, doznania i wspólnie poszukiwana przyjemność. Jeżeli pojawia się zachwyt pięknem, to jest on raczej powierzchowny i przelotny. W kulturze zapping przyjemności szybko się zmieniaja i są rozpraszające. „Uczuciowość nie znajduje sposobu na dojrzewanie”16. Pomimo to Arystoteles jest zdania, że „z tych dwóch rodzajów [przyjaźni: utylitarnej i hedonicznej] bardziej zbliża się do przyjaźni ta forma, która szuka przyjemności i w której obie strony tego samego od siebie nawzajem doznają i cieszą się sobą nawzajem lub tymi samymi rzeczami"17.

Przyjaźń oparta na cnocie, całkowicie odmienna od dwóch poprzednich, jest jedyną prawdziwą i doskonałą formą przyjaźni. Być przyjacielem znaczy w tym przypadku pragnąć dobra drugiego dla niego samego, a nie wykorzystywać go instrumentalnie jako środek do osiągnięcia własnej korzyści ${ }^{18}$.

Trwałość przyjaźni zależy więc nie tylko od emocji, ale czerpie z głębszych pokładów. Pochodzi mianowicie z dyspozycyjności wnętrza ukierunkowanego całkowicie na dobro partnera. Prawdziwa i doskonała przyjaźń wymaga takiej wewnętrznej stabilności i takiej wewnętrznej struktury, którą Arystoteles, a za nim cała tradycja, ze św. Teresą włącznie, nazywa cnotą.

\subsubsection{Dwa typy przyjaźni według św. Teresy od Jezusa}

Sw. Teresa nie zna pism ani etycznych teorii Arystotelesa w ich naukowej wersji. Co do tego nie mamy najmniejszych wątpliwości. Jej refleksje na temat przyjaźni zdradzają jednak pewną intuicyjną ich znajomość. Ponadto dowodzą umiejętnego czerpania z powszechnej kultury i inteligentnego posługiwania się funkcjonujacymi w niej pojęciami i dystynkcjami. Ujawnia to tekst małego „traktatu” o przyjaźni (Dv 4-7). Teresa wie na przykład, że w mniej doskonałych formach przyjaźni zawsze szukamy własnego pożytku i przyjemności, natomiast w miłości doskonałej, bezinteresownej, jesteśmy już wolni od tego rodzaju skupienia na sobie. Pisze:

Przy bliższym zastanowieniu się nad sobą nietrudno spostrzec, że gdy pragniemy, aby nas kochano, zawsze w tym szukamy jakiegoś interesu własnego, pożytku

16 J. VANIER, Il sapore della felicità, s. 62.

17 Etyka nikomachejska, VIII, 6, 1158 a 18-20.

18 „Dwie pierwsze formy przyjaźni mają mniejszą wartość. Więcej nawet, pod pewnym względem są to formy zewnętrzne i iluzoryczne, ponieważ - mówiąc językiem współczesnym - w nich człowiek kocha drugiego człowieka nie ze względu na to, $\mathrm{k}$ i m on je st, lecz tylko ze względu na to, co posiada; przyjaciel w znacznej mierze jest traktowany jako instrument przynoszacy korzyści (bogactwo, przyjemność). Tylko trzecia forma jest autentyczną postacią przyjaźni, ponieważ tylko w jej wypadku człowiek kocha drugiego człowieka ze względu na to, ki m on jest, czyli jego wewnętrzną dobroć jako człowieka". G. Reale, Historia filozofii starozytnej, t. II: Platon i Arystoteles, Lublin 2005, s. 497. 
[ provecho] czy przyjemności [contento]. Lecz dusze doskonałe, o których mówiłam, podeptały już wszelkie dobra [bienes y regalos] i wszelkie pociechy [contentos], jakimi by je ktoś na świecie mógł obdarzyć. I takie jest ich usposobienie wewnętrzne, że chociażby chciały jeszcze pragnąć tych rzeczy, nie mogłyby, bo innej już pociechy [contento] doznać nie zdołają, jak tylko w Bogu albo w sprawach Bożych. Jakiż więc pożytek [provecho] mogą mieć z pragnienia miłości? (Dv 6, 6).

Trzeba zauważyć, że Teresa nie posługuje się Arystotelesowskim podziałem na trzy formy przyjaźni, lecz wyróżnia dwie jej postaci. Jedną jest miłość (przyja źń) d o skonała, czysta, duchowa, cnotliwa, bezinteresowna, i tę Teresa ma przede wszystkim przed oczyma; drugą natomiast miłość (przyjaźń) jeszcze n ie d o sk o n ała, naznaczona zmysłowością i cielesnością, na której pułapki stale zwraca uwagę, ale bynajmniej nie wyklucza jej z tego powodu jako drogi duchowego wzrostu w doskonałości. Co więcej, w kluczowym tekście, w którym dokonuje formalnego rozróżnienia na dwie formy, obie określa przymiotnikiem „duchowa”:

Miłość, o której tu mówię, jest dwojaka. Jedna [czysto] duchowa [espiritual], bo nic zmysłowego ani żadna tkliwość uczucia przyrodzonego do niej nie ma przystępu i nie mąci jej czystości; druga [również] duchowa [espiritual], ale z domieszką przyrodzonej zmysłowości i słabości $(\text { Dv } 4,12)^{19}$.

Rozróżnienie na dwie formy miłości (przyjaźni), w istocie doskonale odpowiadające Arystotelesowskiemu rozróżnieniu na trzy ${ }^{20}$, Teresa przejęła z filozoficznej tradycji średniowiecza, której udało się połączyć pozytywne wątki filozofii Platona i filozofii Arystotelesa i zasymilować je z myślą chrześcijańskąa ${ }^{21}$. Filozofia ta rozróżniała jedynie amor concupiscentiae i amor benevolentiae, to znaczy miłość naznaczoną pożądaniem i miłość życzliwą ${ }^{22}$. Miłość pierwszego typu, amor concupiscentiae, wy-

19 „Domieszka” zmysłowości do czystej miłości duchowej przypomina „mieszanie” przyjemnósi z czystym rozumem, o którym Platon mówi w Filebie, $63 \mathrm{~A}$, aż do końca dialogu, pokazując, że na tym polega „zwyczajny" sposób bytowania czlowieka. Platon i, jak za chwilę zobaczymy, Teresa dalecy są od abstrakcji, o którą ich się czasami posądza.

20 Chociaż Arystoteles mówi o trzech rodzajach przyjaźni (utylitarnej, hedonicznej i cnotliwej), to jednak - jak widzieliśmy - dwie pierwsze można sprowadzić do jednej, obie są też mniej wartościowe, nie są doskonałe.

21 Por. E. Berti, Nuovi studi aristotelici. IV/1 - L'influenza di Aristotele. Antichità, Medioevo e Rinascimento, Brescia 2009, szczególnie rozdział czwarty z drugiej części, zatytułowany San Tommaso, commentatore di Aristotele, s. 155-166.

22 Sw. Tomasz z Akwinu opiera to rozróżnienie na następującym fundamencie antropologicznym: „Życie ludzkie jest dwojakie: jedno zewnętrzne, naturą zmysłową i cielesną, i pod tym względem nie mamy łączności i obcowania $\mathrm{z}$ Bogiem czy też z aniołami. Jest jednak w człowieku życie duchowe, umysłowe, i tym możemy obcować $z$ Bogiem i z aniołami, choć w obecnym stanie nie jest to obcowanie pełne, jak powiada Apostoł (Flp 3, 20): "nasze obcowanie w niebie jest «; obcowanie to będzie jednak udoskonalone w niebie, gdzie »słudzy Jego służą Bogu i widzieć będą oblicze Jego« (Ap 22, 3-4). Przeto tutaj miłość nie jest doskonała, ale udoskonalona zostanie w ojczyźnie 
stępuje wówczas, gdy kocham drugiego, ale jeszcze jako część mojego własnego świata, czyli - jak mówił Arystoteles - z powodu korzyści albo przyjemności, jakich on mi dostarcza; gdy przestaje mi ich dostarczać, moja miłość do niego się urywa i już nie traktuję go jak przyjaciela. Natomiast miłość drugiego typu, czyli amor benevolentiae, występuje wtedy, gdy kocham drugiego - znowu jak mówił Arystoteles - ze względu na niego samego. Św. Tomasz z Akwinu, nawiązując wprost do filozofa, tak pisze o tej ostatniej: „Arystoteles w Etyce [nikomachejskiej, VIII, 2] powiada, że nie jakiekolwiek lubienie ma charakter miłości, ale lubienie, które połaczone jest z życzliwością, a mianowicie wówczas, gdy kogoś lubimy, życząc mu dobra"23.

Św. Teresa nie poprzestaje na tych rozróżnieniach. Obie formy miłości (przyjaźni) stara się opisać i przybliżyć swoim czytelnikom. Zaczyna od miłości niedoskonałej. Jest ona taka, poniewaź niedoskonała, skończona, słaba i krucha jest ludzka natura, skażona grzechem. Z tej właśnie racji - mówi Święta, majac na uwadze omawiane przez siebie Jezusowe przykazanie miłości - „nigdy nie umiemy wypełnić go doskonale" (Dv 4, 5). Konkretnie: naturze naszej brakuje harmonii między sferą uczuciową (zmysłową) i poznawczą (rozumną), tak że wola nie umie już i nawet nie wie, co wybierać. W tej właśnie sferze, i żadnej innej, Teresa dostrzega całą dysharmonię i rozstrojenie naszej natury. Tutaj widzi przyczynę i źródło wszelkiego zła, to znaczy wszelkich zawikłań i sprzeczności, w jakie popadają poszczególne dusze i cała wspólnota. „O Boże, ile z tego źródła wynika niedorzeczności i rozlicznych postępków” (Dv $4,8)$. To jest też miejsce wielu niepotrzebnych udręczeń i niepokojów duszy, która sama sobie nie radzi, a nie znajduje nikogo, kto by jej pomógł zrozumieć bolesną konieczność oderwania od samej siebie i radosną wolność kochania bezinteresownego.

Pr zywi ąz an ia, o których wciąż mówi i które, zdaje się, najbardziej charakteryzują tę niedoskonałą formę miłości, w rzeczywistości są skutkiem wcześniejszego nieuporządkowanego szukania własnych korzyści i przyjemności. Twierdzi więc kategorycznie: „Nie widzę z nich żadnego pożytku, najczęściej zaś [... obracają się one w truciznę" (Dv 4,7). Niemniej jednak ta niedoskonała forma miłości stanowi zwyczajną drogę, po której idziemy do miłości czystej i doskonałej. Święta tej drogi nie kwestionuje, choć mocno ją obwarowuje: „Przy zachowaniu należnej powściagliwości i roztropności miłość taka zupełną ma zasługę, i to nawet, co w niej zdaje się być zmysłowego, zamienia się w cnotę [se torna en virtud]" (De 7,1 ).

Ponadto Teresa uczy nas konkretnie, że gwałtowne rozbudzenie uczuć w relacjach z osobami, które nas rozumieją, i niepokój, jaki z tego powodu się w nas pojawia, nie stanowi jeszcze wystarczającego powodu do wycofania się z tej relacji. Lekarstwem na ten niezrozumiały niepokój jest... większa i czystsza miłośc:

niebieskiej”. STh II-II, qu. 23, art. 1, ad. 1. Por. R. Spaemann, Szczęście a życzliwość. Esej o etyce, Lublin 1997, s. $147-159$.

23 STh II-II, qu. 23, art. 1. 
Nieraz dusza taka, choć widzi i czuje, że spowiednik swoim kierunkiem skutecznie prowadzi ją do doskonałości, porzuca go, chcąc położyć koniec udręczeniu swemu [wynikającemu z przywiązania do spowiednika]; ale choć opuściwszy jednego, uda się do drugiego i trzeciego, diabeł nie przestaje jej nękać wciąż tą samą pokusą. Najlepsza na to rada, starać się wcale o tym nie myśleć ani się troszczyć o to, czy kochasz, czy nie kochasz. Czujesz, że kochasz? Więc kochaj i bądź spokojna. [...] Przywiązanie do niego może być bardzo skutecznym czynnikiem wysokiego postępu w cnocie i $[\ldots]$ pomocą do podjęcia rzeczy wielkich i trudnych w służbie Bożej (De 7,2).

Według św. Teresy, nie możemy czekać, aż osiągniemy miłość doskonałą; jeśli nie zaczniemy kochać od razu, teraz, choćby w sposób niedoskonały, nigdy nie dojdziemy do celu. Istotne jest, aby na podstawie aktualnych możliwości stale dążyć do duchowej dojrzałości uczuć, mając na uwadze cechy, jakie ma miłość doskonała.

Miłość czysto duchowa, doskonała, jest miłością przyjaźni nadprzyrodzonej, której źródłem i dawca jest Pierwszy Przyjaciel. Teresa mówi: „od Niego pochodzi ta miłość i życzliwość" (Dv 6, 5). Jednocześnie ma świadomość, że ta mitość nie zatrzymuje się egoistycznie tutaj na ziemi. Wraca z powrotem do Pierwszego Przyjaciela, zabierając ze sobą wszelkie ziemskie przyjaźnie:

Jest to - powtarzam - miłość w najmniejszej mierze dbająca o siebie; o to jedynie dba, by tę duszę, którą kocha, ujrzała bogatą w dobra niebieskie $(\mathrm{Dv} 7,1)$.

Stąd wiele zyskują ci, którzy mają takich przyjaciół, bo prędzej czy później pociągną ich na swoją drogę, gdyż zdążają do jednej krainy jak św. Monika ze św. Augustynem (Dv 7, 4).

Ta doskonała miłość, jak widzimy, traktuje osobę jako osobę, to znaczy serio. Kocha ją dla niej samej, a nie ze względu na jej przymioty lub przelotne okoliczności czy też ze względu na siebie samą (egoistycznie):

Dusze wyższym światłem oświecone nie troszczą się o to, czy je k to kocha czy nie. [...] Ich miłość jest szlachetna, zawsze ochotna dawać raczej niż brać. Względem Boga tak samo postępują. Tylko taka miłość godna jest tej nazwy, a wszelkie inne niskie przywiązania przywłaszczają tylko miano miłości (Dv 6,7).

Św. Teresa, idąc za św. Tomaszem ${ }^{24}$ i w duchu Platona, ale wbrew Arystotelesowi ${ }^{25}$, nie dopuszcza myśli, by czysta i doskonała miłość przyjaźni mogła szukać

24 Por. tamże, II-II, qu. 23, art. 1, arg. 3 i ad. 3.

25 Por. Etyka eudemejska, VII, 2, 1236 b 12-26, gdzie Arystoteles polemizuje z Platonem. Por. W. JANUSIEwICZ, La sapienza è amicizia nella Summa Theologica di Tommaso d'Aquino, Roma 2012, 
własnej korzyści albo własnej przyjemności. Jest ona, według niej, całkowicie ukierunkowana na dobro przyjaciela, powszechna, bezinteresowna, bezwarunkowa, darmowa i stale pierwsza wychodzi ku drugiemu. Jest ponadto czynna i konkretna, to znaczy wyraża się w uczynkach. Jest zdolna i współweselić się, i współczuć z przyjacielem. Potrafi poświęcić dla niego własne życie. Miłuje bowiem dobro, jakie Bóg złożył w drugim, i widzi go zawsze jako dzieło Stwórcy. Jest trwała. Stale dąży do wieczności pełnej miłości.

Komuś może się wydawać, że miłość doskonała, oparta na cnocie, jest - w przeciwieństwie do miłości niedoskonałej - abstrakcyjna i stanowi czysty, nieuchwytny dla śmiertelnika ideał. Teresa jest jednak zupełnie odmiennego zdania.

Miłość prawdziwa natychmiast się objawia. Nie pojmuję nawet, jak by się mogła ukryć? Jeśli miłość do stworzenia nie może się ukryć, jeśli ta miłość ziemska, niegodna nawet tej nazwy, choćby ją ukrywano, zawsze wyjdzie na jaw - któż jeszcze odważy się twierdzić, by mogła pozostać ukryta i nie poznana miłość Boża? [...] Jakże głęboko musi odczuć, jak jasno widzieć ogromną różnicę tej miłości od tamtej, komu raz dano jej zakosztować! (Dv 40,7)

\subsection{Przyjaźń jako cnota}

W niniejszym paragrafie pogłębimy poprzedni temat, skupiając uwagę na przyjaźni autentycznej, to znaczy opartej na cnocie (Arystoteles) albo doskonałej (św. Teresa). Chociaż nasi autorzy używają tu odmiennego nazewnictwa, albo raczej stosują je zamiennie, to jednak rzeczywistość, którą mają na uwadze, jest ta sama. Tylko przyjaźń oparta na cnocie, doskonała, czysta, duchowa, zasługuje na to zaszczytne miano.

Arystoteles z całym poczuciem realizmu stwierdza jednak: „wypadki takiej przyjaźni są rzadkie; niewielu jest bowiem takich [cnotliwych] ludzi" ${ }^{26}$. Teresa mu wtóruje: „Miłość czysto duchowa [przyjaźń] [...] jest udziałem niewielu” (Dv 6, 1). Co jest przyczyną tej „elitarności” cnoty przyjaźni? Odpowiedź na to pytanie dzisiaj może się okazać niełatwa. Począwszy bowiem od XIX wieku, zagadnienie przyjaźni przywykliśmy rozpatrywać wyłącznie w kluczu psychologicznym. Myślimy o niej prawie zawsze w kontekście uczuć i wewnętrznych przeżyć. Mieszamy ją z naturalistyczną koncepcją miłości romantycznej. Zdaje się nam, że musi być dostępna na każde nasze zawołanie i bezwarunkowo możliwa dla wszystkich. Stanowisko Arystotelesa, a jesz-

s. 201. G. Reale (Historia filozofii, t. II, s. 497-498) pisze: „Arystoteles zupełnie jasno twierdzi, że nawet w przyjaźni opartej na cnocie przyjaciel szuka w przyjacielu własnego dobra. Przyjaźń pojęta jako be z in te re s ow ny dar siebie dla drugiego jest koncepcją całkowicie obcą Arystotelesowi. Nawet na najwyższym stopniu przyjaźń jest pojęta jako relacja dawania i posiadania”. I nieco dalej cytuje Arystotelesa: „I kochając przyjaciela, kochają to, co jest dla nich dobre...” (Etyka nikomachejska, VIII, 5,1157 b 33 n.). 
cze bardziej św. Teresy nie tylko podważa taką „szeroką drogę” przyjaźni, ale przede wszystkim stanowi zaproszenie do głębszej refleksji i pomoc w wyzbyciu się iluzji.

\subsubsection{Przyjaźn jako cnota wedtug Arystotelesa $a^{27}$}

Arystoteles nazywa przyjaźń „cnotą” i umieszcza ją na trzech listach cnót moralnych, jakie zostawił w swoich trzech Etykach. Jako cnota jest ona „słusznym środkiem” pomiędzy dwiema wadliwymi skrajnościami, mianowicie nadmiarem i niedostatkiem. W tym przypadku owymi skrajnościami są pochlebstwo (nadmiar) i wrogość (niedostatek).

W Etyce eudemejskiej, oprócz zamieszczenia przyjaźni na liście cnót moralnych i podania przeciwnych jej wad ${ }^{28}$, czytamy takie słowa:

Przyjaźń jest stanem umiaru [słusznym środkiem] pomiędzy wrogością a pochlebstwem. Kto bowiem łatwo pod każdym względem przystosowuje się do pragnień innych, ten jest pochlebcą, kto we wszystkim się przeciwstawia, ten jest nieżyczliwy, a kto ani nie biegnie za każdą przyjemnością, ani każdej się nie przeciwstawia, tylko dąży do tego, co okazuje się najlepsze, ten jest przyjazny ${ }^{29}$.

W Etyce wielkiej ta sama myśl zostaje powtórzona i rozwinięta w następujący sposób:

Przyjaźń jest umiarem [słusznym środkiem] pomiędzy pochlebstwem i nienawiścią, a dotyczy czynów i słów. Bo pochlebcą jest ten, kto przypisuje komuś więcej zalet, niż się godzi i niż jest w rzeczywistości. A nienawistny jest wrogo usposobiony do bliźniego i ujmuje mu zalet. A zatem żadnego z nich naprawdę nie można pochwalić, a przyjazny znajduje się pośrodku pomiędzy nimi, bo ani więcej nie doda, niż jest, ani nie pochwala tego, co nie zasługuje na to, ani odwrotnie, niczego nie pomniejsza, ani w żadnych okolicznościach nie będzie się sprzeciwiał wbrew swemu przekonaniu. Taki więc jest człowiekiem przyjaznym ${ }^{30}$.

W Etyce nikomachejskiej nie jest wprawdzie wprost powiedziane, że przyjaźń jest cnotą moralną, a tylko że jest do niej bardzo zbliżona, niemniej trzeba zauważyć, że Arystoteles nie mówi w tym miejscu o przyjaźni jako takiej, lecz o przyjaznym nastawieniu do ludzi, które w języku greckim, według niego, nie ma odrębnego imie-

27 W tym paragrafie wiele zawdzięczam i w znacznym stopniu śledzę tok myśli A. FerMANI, L'etica di Aristotele. Il mondo della vita umana, Brescia 2012, s. 83-86.

28 Etjka eudemejska, II, 3, 1221 a 7.

29 Tamże, III, 7, 1233 b 29-35.

30 Etyka wielka, I, 31, 1193 a 20-27. 
nia. Ta bezimienna postawa „zbliża się jednak najbardziej do przyjaźni” i też stanowi „środek" pomiędzy wadliwymi skrajnościami. Oto jego słowa:

W stosunkach towarzyskich, współżyjąc i stykając się z ludźmi w rozmowach i w interesach, jedni zdają się być ugrzecznieni, ci mianowicie, którzy chcą drugim sprawić przyjemność, wszystko chwalą i w niczym się nikomu nie sprzeciwiają, lecz uważają za swój obowiązek nie sprawiać przykrości tym, z którymi się stykają; w przeciwstawieniu zaś do tych, inni starają się na każdym kroku wszystkiemu się sprzeciwiać i nie troszczą się bynajmniej o niczyją przykrość; ci noszą miano gburów i ludzi swarliwych. Jasne, że obie wspomniane trwałe dyspozycje są nagany godne i że na pochwałę zasługuje leżąca pomiędzy nimi dyspozycja, dzięki której człowiek zarówno darzy uznaniem, jak też potępia to, co należy, i tak, jak należy; ta środkowa dyspozycja jest bezimienna, zbliża się jednak najbardziej do przyjaźni ${ }^{31}$.

Ten ostatni tekst, z Etyki nikomachejskiej, naprowadza nas na drugą cechę przyjaźni, która czyni ją cnotą moralną. Chodzi o s praw ność albo dy s pozy cję do dobra (habitus, hexis): „Przyjaźń jest pewnego rodzaju dyspozycją moralną”32.

Co to znaczy, że przyjaźń jest „dyspozycją”, albo nawet „trwałą dyspozycją”? Znaczy to, że jest wytwarzana przez świadome wybory i postanowienia. Faktycznie, każdy wybór „słusznego środka” pomiędzy wadliwymi skrajnościami, tj. pomiędzy nadmiarem i niedostatkiem, wymaga pewnego namysłu. Dokonywane w ten sposób wybory kształtują charakter, wytwarzając w nas coraz większą skłonności i dyspozycyjność do dobra, jakim jest przyjaźn. Kolejne zaś przyjazne czyny sprawiają, że stajemy się rzeczywistymi przyjaciółmi. To wszystko oznacza, że przyjaźn nie jest jakimś zmiennym uczuciem ani żadną naturalną namiętnością, lecz osobowym, świadomym i wolnym wyborem. W Etyce nikomachejskiej autor mówi wprost: „Miłość jest namiętnością, przyjaźń zaś trwałą dyspozycją. [... I ludzie życzą dobrze tym, dla których żywią uczucie przyjaźni ze względu na nich samych, idąc za nakazem nie uczucia, lecz trwałej dyspozycji”" ${ }^{33}$.

Przyjaźń, jako cnota, stanowi dobro duszy. Arystoteles dzieli dobra na trzy grupy: niektóre są dobrami duszy, inne dobrami ciała (zdrowie i piękno), inne jeszcze dobrami zewnętrznymi (bogactwo, władza, zaszczyty...). Spośród nich wszystkich dobra duszy są „najbardziej wartościowe”. Filozof wyróżnia trzy ich rodzaje: „mądrość, doskonałość (arete, cnota) i przyjemność" ${ }^{34}$.

31 Etyka nikomachejska, IV, 6, 1126 b 10-15.

32 Etyka eudemejska, VII, 1, 1234 b 27-28.

33 Etyka nikomachejska, VIII, 5, 1157 b 28-29.

34 Etyka wielka, I, 3, 1184 b 1-5. 


\subsubsection{Przyjaźn jako cnota według św. Teresy od Jezusa}

Św. Teresa od Jezusa, podejmując rozważania na temat „wzajemnej miłości między nami” (Dv 4, 5), zamiennie używa słów „miłość” i „przyjaźn”, podobnie zresztą jak słów „przykazanie” i „cnota”. O tych ostatnich już wspominałem $\left(3.1 .3^{35}\right)$, natomiast na temat relacji między przyjaźnią a miłością powiemy w osobnym podrozdziale (3.7), gdyż zasługuje ona na szczególną uwagę. W tym miejscu ważne jest, że Święta ma jasne pojęcie miłości/przyjaźni właśnie jako cnoty.

Zaraz na samym początku rozważań na temat wzajemnej miłości/przyjaźni Teresa pisze:

Co do [...] wzajemnej między nami miłości, trudno i wypowiedzieć, jak niezmiernie wiele od niej zależy. Nie ma rzeczy tak trudnej, której by miłujący siebie z łatwością nie znieśli i szczególnie ciężkiej potrzeba by na to przykrości, by im się wydała trudną do zniesienia. Gdyby to przykazanie miłości bliźniego było zachowywane na świecie, tak jak by należało, sądzę, że przyczyniłoby się wiele do zachowania innych $(\mathrm{Dv} 4,5)$.

Innymi słowy, gdybyśmy zachowywali to Jezusowe przykazanie, albo raczej gdybyśmy tę miłość, którą Jezus nam przykazuje, nabywali tak, jak nabywa się wszystkie inne cnoty: przez codzienną praktykę, ćwiczenie, nieustanne powtarzanie konkretnych czynów (aktów) miłości, aż do osiaggnięcia pewnego nawyku, przyzwyczajenia, sprawności, aż do wytworzenia się w nas owego słynnego habitus, czyli trwałej postawy, trwałej dyspozycji do pełnienia dobra, wówczas - zgodnie z wewnętrznymi prawidłami cnoty - każda rzecz, każda trudność, każda przykrość okazałyby się łatwe do zniesienia, a nadto łatwe byłyby do zachowania również wszystkie inne przykazania, obowiązki i powinności. Cnota bowiem, zgodnie z klasycznym, arystotelesowskim jej rozumieniem, ma to do siebie (ma tę urodę), że pozwala nam realizować pewne czyny w sposób lekki, łatwy i przyjemny. „Cnota - pisze konkretnie Teresa - ma w sobie wdzięk i urok, który pociąga serce do jej umiłowania [ la virtud siempre convida a ser amada]. A ufam w milosierdziu Pana, że w tym domu i u sióstr do niego należących c nota zawsze mieszkać będzie" (Dv 4, 10).

Teresa ma tę nadzieję, ale jednocześnie jest wielką realistką: „Niestety - przez nadmiar lub niedobór - nigdy nie umiemy go [Jezusowego przykazania cnoty miłości] wypełnić doskonale" (Dv 4,5). Pisze i daje do zrozumienia, że wie, gdzie leży źródło naszego moralnego problemu. Teresa lokuje je w owym bardzo osobliwym más o menos („mniej więcej”), które w dawnym przekładzie ks. bpa Kossowskiego zostało zupełnie pominięte, natomiast w wielu współczesnych tłumaczeniach jest oddane przez terminy techniczne, zaczerpnięte z etyki: „nadmiar lub niedobór”.

35 Zob. „Itinera Spiritualia” X (2017), s. 168-172 (przyp. red.). 
Ja w powyższym tłumaczeniu również się nimi posłużyłem, chociaż Teresa użyła tu prostego wyrażenia $z$ języka potocznego, nad którym często przechodzimy bez szczególnego namysłu, a które przecież oddaje ten sam filozoficzny problem. Teresa jakby chciała nam powiedzieć: „ponieważ w naszym życiu wszystko jest »mniej więcej«, dlatego nie dziwcie się, że nie udaje nam się zachować miłości z należną doskonałością”. W jej przekonaniu wszystkie problemy w życiu miłości sprowadzaja się do owego „mniej więcej”.

Nic więc dziwnego, że po tym ogólnym wprowadzeniu Teresa od razu przechodzi do konkretów i zaczyna piętnować jedną z owych wadliwych skrajności, mianowicie - i co ciekawe! - najpierw nadmiar. „Mogłoby się zdawać, że zbytnia [más!] między wami miłość nigdy nie może być rzeczą złą" (Dv 4, 5) - tak zaczyna się długi wywód Teresy na temat owej más miłości ( „zbytniej”, „zbyt dużej”, „przesadnej”, „nadmiernej”), która zdawałaby się czymś niewinnym -

a jednak - kontynuuje - tyle ona sz kód wyrządza i takie pociąga za sobą niedoskonałości, że nikt temu nie da wiary, kto sam tego nie doświadczył. Mnóstwo tu szatan wznieca zawikłań, na które sumienia, powierzchownie tylko traktujące służbę Bożą, mało zważają, owszem, wydaje im się to cnotą. Dusze jednak naprawdę dążące do doskonałości jasno widzą, czym to grozi, iż powoli i nieznacznie podkopuje siłę woli i odciąga je od całkowitego oddania się miłości Bożej (Dv 4, 5).

Święta więc, która „jasno widzi” liczne niebezpieczeństwa związane ze „zbytnią” miłością/przyjaźnią, piętnuje jej różne przejawy: „tracenie czasu na rozmowy nie tyle o miłości Bożej, ile raczej o tym, jak ją sama kocha i o innych głupstwach" (Dv 4,6), używanie pochlebstw w stylu "moje serce, moje życie, mój skarbie” czy innych pieszczotliwych słów (Dv 7,8), dawanie upustu swoim namiętnościom, czułościom, „gniewowi, smutkowi" w swoistej grze uczuć o miłość siostry (por. Dv 4, 6), zabieganie o rzeczy materialne, którymi mogłaby obdarzyć umiłowaną (tamże), rezygnowanie z równości charakteryzującej przyjaźń i przyjmowanie postawy niższości, zmierzającej do pozyskania miłości współsiostry (tamże), kompulsywne stawanie w obronie umiłowanej, którą „spotkała jakaś krzywda” (tamże). Przejawów tej „zbytniej” miłości/przyjaźni wymienia znacznie więcej, a najbardziej charakterystycznym jest przywiązywanie osób do siebie i przyjaźnie partykularne, które omówiłem wcześniej $\left(3.3 .3^{36}\right)$. Wszystko to, zamiast otwierać ludzkiego ducha na odpowiednią dla niego nieskończoność, uwodzi go ziemskimi mamidłami i krępuje cielesnymi więzami, by ostatecznie zamknąć w ciasnej klatce plaskiego horyzontalizmu i odciaggnać „od całkowitego oddania się miłości Bożej” (Dv 4,5).

Interesująca jest rzeczą, że tuż obok pojawia się druga wadliwa skrajność miłości/ przyjaźni, jaką jest jej niedobór. W ujęciu Teresy - dokładnie tak samo, jak u Arysto-

36 Zob. „Itinera Spiritualia” X (2017), s. 185-191 (przyp. red.). 
telesa - wyraża się ona w postawie wrogości i nienawiści. Według niej, ta wada stanowi „główne źródło ruiny życia zakonnego" (Dv 7, 10). Nie chodzi jej jednak tylko o jakieś „słowo nierozważne”, które mąci zgodę między siostrami i któremu należy natychmiast zaradzić „wielką modlitwą” (tamże), ale przede wszystkim o bardziej trwałe, „zagnieżdżone między siostrami głębsze zdrożności”, jak „chęć podobania się lub wywyższenia nad drugich” czy też „urazy obrażonej miłości własnej” (tamże). Teresa zdaje sobie sprawę, że osoby wrogo do siebie usposobione przyjmują w swojej pysze postawę wyższości wobec innych i wprowadzają podziały, tworząc małe, zamknięte w sobie i wykluczające innych grupy i stronnictwa. Zwykle działają w sposób przebiegły, skrycie dążą do władzy, a nadto zgłaszają - być może dla przykrycia swych niecnych działań - monopol na miłość. Teresa wie, że ten rodzaj „miłości” w zamkniętej wspólnocie klauzurowej jest przyczyną wszelkich rozłamów, a więc ostatecznego zła: „wtedy już miejcie się za stracone i wiedzcie, żeście wygnały Pana $z$ tego domu”. W tej sytuacji poleca: „Wołajcie o zmiłowanie do Boskiego Majestatu Jego, błagajcie Go o ratunek, bo jeśli taka częsta spowiedź i Komunia nie zdoła takim zdrożnościom zapobiec, słusznie macie się obawiać, czy nie ma między wami jakiego Judasza" (Dv 7, 10). Nie wylklucza również sięgnięcia po drastyczne środki: odesłanie sprawcy zamieszania ze wspólnoty, a na pewno „stłumienie zarazy w samym jej zawiązku" (Dv 7, 11).

Gdyby św. Teresa miała wybierać pomiędzy tymi dwiema wadami, z pewnością wybrałaby pierwszą. W pierwotnym rękopisie Drogi doskonatości sama daje temu wyraz:

[...] lepiej już kochajcie się między sobą miłością choćby mniej doskonałą niż ta, którą wam opisuję, miłością tkliwą i pieszczotliwą, byleby równą dla wszystkich, niż gdyby miała być między wami jaka bądź najmniejsza niezgoda. Od tego niechaj Pan was broni wedle boskiego miłosierdzia swego, amen (De 11, 11).

W rzeczywistości jednak Teresa dąży do prawdziwej doskonałości i autentycznej cnoty. Nie zadowala się powierzchownymi i złudnymi jej wyrazami, ale stale szuka „„łusznego środka”, gdyż wie, że in medio stat virtus. Siostrom więc poleca: „Miłujmy cnoty i dobro wewnętrzne [amemos las virtudes y lo bueno interior], a ustawicznie $\mathrm{z}$ wszelką troskliwością czuwajmy nad sobą, abyśmy miały serce nie przywiązujące żadnej wagi do powabów zewnętrznych" (Dv 4,7).

\subsection{Przyjaźń jako uczucie (namiętność)}

Inny aspekt przyjaźni, szeroko rozwijany zarówno przez Arystotelesa, jak i św. Teresę od Jezusa, to przyjaźń rozumiana jako uczucie albo namiętność. Może się wydawać, że takie ujęcie stanowi zaprzeczenie wszystkiego, co powiedzieli oni o przyjaźni jako cnocie (por. 3.5) . Potoczne bowiem rozumienie uczuć jako bezpośrednich doznań cielesnych, wzmocnione przez psychologię empiryczną, romantyzm i współ- 
czesną kulturę hedonistyczną, nasuwa wszakże myśl o „szerokiej drodze”, na której przyjaźń staje się dostępna dla każdego, na każde zawołanie, i nie musi już być doświadczeniem „elitarnym”, zarezerwowanym jedynie dla tych, którzy oddają się cnocie.

Trzeba jednak powiedzieć, że Arystoteles i św. Teresa zdecydowanie odcinają się od tego rodzaju potocznych ujęć i przedstawiają własne filozoficzne rozumienie uczuć. Według nich, uczucia nie są mechanicznymi impulsami ślepej natury, które popychałyby nas i pociagały niezależnie od naszych rozumowań i przekonań, lecz są całkowicie od nich uzależnione: jakakolwiek zmiana naszego sposobu myślenia i przekonań wiary oznacza i pociąga za sobą jednoczesną zmianę naszych uczuć. Uczucia mają tu więc charakter kognitywny i są ściśle związane z ludzkimi przekonaniami. Mogłyby one być „irracjonalne” tylko wówczas, gdyby przekonania, na których się opierają, były fałszywe albo źle uargumentowane ${ }^{37}$.

Takie rozumienie uczuć nie tylko nie prowadzi do żadnego konfliktu między dwoma omawianymi ujęciami przyjaźni - jako cnotą i jako uczuciem - ale stanowi ich dopełnienie i pogłębienie: cnota przyjaźni sprawdza się w realnych warunkach, to znaczy w krzyżowym ogniu uczuć/namiętności; natomiast uczucia przyjaźni dzięki cnocie nabierają charakteru uniwersalnego. Zobaczmy, w jaki sposób Arystoteles i św. Teresa argumentują swoje filozoficzne stanowiska w kwestii przyjaźni jako uczucia.

\subsubsection{Przyjaźn jako uczucie według Arystotelesa}

Przyjaźn, podobnie jak wszystkie inne cnoty etyczne i dianoetyczne, i w ogóle wszystko, co istnieje, może być, zgodnie ze słynną formułą Arystotelesa, pollachos legomenon - wyrażona na wiele sposobów ${ }^{38}$. Może więc być powiedziana (widziana) nie tylko jako cnota, ale także jako uczucie. I rzeczywiście, na liście uczuć/namiętności, jaką filozof zestawił w Etyce nikomachejskiej, obok wielu innych umieścił również przyjaźń. Wymienia ją na siódmej pozycji: „Namiętnościami nazywam: pożądanie, gniew, strach, odwagę, zawiść, radość, przyjaźń [philia], nienawiść, tęsknotę, zazdrość, litośé” 39 . Zaskoczenie budzi fakt, że w tym samym tekście, nieco dalej, Arystoteles wyraźnie pisze, iż uczucie (namiętność) jest rzeczywistością, która w żaden sposób nie może być utożsamiona z cnotą:

Do namiętności nie należą ani cnoty, ani wady etyczne, ponieważ nie nazywają nas ani dobrymi, ani złymi z powodu namiętności, natomiast nazywają nas

37 Por. M. Nussbalm, Terapia del desiderio. Teoria e pratica nell'etica ellenistica, Milano 1998, s. 44. Por. również prace tej samej autorki: Upheavals of Thought: A Theory of the Emotions, Cambridge 2001; Emotions as Judgments of Value, „Yale Journal of Criticism” 5 (1992), s. 201-212.

38 Por. A. Fermani, L'etica di Aristotele, s. 7-20, a zwł. s. 94-98; M. SMOLaK, Przyjaźn w świetle etyki Arystotelesa, s. 25-37.

39 Etyka nikomachejska, II, 5, 1105 b 19-21. 
w ten sposób z powodu cnót lub wad etycznych; ponieważ dalej ze względu na namiętności nie otrzymujemy ani pochwał, ani nagany $[\ldots]$, otrzymujemy natomiast pochwały i nagany ze względu na cnoty i wady ${ }^{40}$.

Z powyższego fragmentu jasno wynika, że jeśli przyjaźń jest uczuciem (namiętnością), to w żaden sposób nie może być jednocześnie cnotą, czyli trwałą dyspozycją (hexis, habitus) do pełnienia dobra. I skoro jest uczuciem, to - przypomnienie ważne także z pedagogicznego punktu widzenia - nikt nie może być z jej powodu ani chwalony, ani ganiony, gdyż pochwała albo nagana może być co najwyżej za dobre lub złe z niej korzystanie i przekształcanie jej w cnotę lub wadę, nigdy zaś za samo jej przeżywanie (doznawanie).

Skoro tak się mają rzeczy - pisze Arianna Fermani - to przyjaźń jako cnota i zarazem jako uczucie przedstawia nam się jednocześnie jako zdolność kierowania i jako to, co ma być kierowane; jako to, czego się doznaje (to znaczy jako uczucie), i jako to, co pozwala nam dobrze doznać owego uczucia (to znaczy jako cnota ${ }^{41}$.

W innych miejscach swoich Etyk Arystoteles zdaje się przedstawiać bardziej subtelne odcienie znaczeniowe tej samej kwestii. W ósmej księdze Etyki nikomachejskiej, a więc w traktacie o przyjaźni, mając prawdopodobnie w pamięci wcześniejsze (księga druga) wpisanie jej na listę uczuć (namiętności) i wykluczenie z rzędu cnót, czuje potrzebę przybliżenia jej jednak do cnoty. W sposób bardziej oględny mówi więc, że przyjaźń jest „pewną cnotą lub czymś z cnotą związanym”"42. Nie wskazuje wprost czym, ale łatwo się domyślić, że jest ona uczuciem, które towarzyszy cnocie i się z nią ściśle wiąże, ale samą cnotą nie jest, albo raczej - nie jest cnotą we właściwym tego słowa znaczeniu, a tylko pewną cnotą.

W czwartej zaś księdze tej samej Etyki nikomachejskiej, jeszcze jakby „,na fali” swej wcześniejszej wypowiedzi o przyjaźni jako uczuciu, a mając na uwadze pewną „bezimienną” trwałą dyspozycję, a więc cnotę, której „słuszny środek” znajduje się pomiędzy ugrzecznieniem a gburowatością (zob. 3.5.1.), twierdzi, że chociaż owa dyspozycja jest zbliżona do przyjaźni, to jednak nią nie jest właśnie dlatego, że brakuje jej uczucia. Na podstawie tego negatywnego założenia Arystoteles może pozytywnie stwierdzić: „Człowiek bowiem postępujący w myśl owej [... t trwałej dyspozycji, jeśliby łączył z nią jeszcze uczucie przywiązania, byłby [dopiero wtedy!] właśnie taki, jakiego mamy na myśli, mówiąc o dobrym przyjacielu"43. Innymi słowy, przy-

40 Tamże, II, 5, 1105 b 28-1106 a 2.

41 A. Fermani, L'etica di Aristotele, s. 87.

42 Etyka nikmachejska, VIII, 1, 1155 a 4: „Pozostaje nam obecnie omówienie przyjaźni; jest ona bowiem pewną cnotą lub czymś z cnotą związanym, a ponadto jest czymś dla życia najkonieczniejszym". Por. A. Fermani, L'etica di Aristotele, s. 86; G. Pellegrini, Il bene e l'apparenza, s. 188. 
jaźń występuje wtedy i tylko wtedy, gdy towarzyszy jej uczucie, bez niego natomiast mamy do czynienia jedynie z jakąś „bezimienną” trwałą dyspozycją, która ma swój „słuszny środek” pomiędzy ugrzecznieniem a gburowatością i jest podobna do przyjaźni, ale nią jeszcze nie jest. $Z$ tego wynika, że gdzie nie ma uczucia, ta m nie ma przyjaźni ${ }^{44}$.

Arianna Fermani w swoim studium możliwych „scenariuszy” albo „figur” przyjaźni zastanawia się, czy istnieje możliwość wyjścia z tego labiryntu pojęciowego, w jakim de facto znajduje się przyjaźń, i czy ową wielość modeli interpretacyjnych i diametralnie przeciwległych perspektyw można w jakiś sposób usprawiedliwić i doprowadzić do pojednania, tak by nie tworzyły wewnętrznej sprzeczności. Zauważa, że można je wszystkie ostatecznie sprowadzić do dwóch podstawowych, wyakcentowanych również w niniejszym studium: $z$ jednej strony do przyjaźni jako cnoty, z drugiej do przyjaźni jako uczucia. Opierając się na lekturze tekstów Arystotelesa, dochodzi ona do następujących wniosków:

1) po pierwsze, przyjaźn jest, zawsze i koniecznie, pewnym uczuciem (namiętnością). Faktycznie - jak to było wykazane - gdy nie ma uczucia, zachodzi inny rodzaj związku, który jest bardzo zbliżony do przyjaźni, jednak w ścisłym tego słowa znaczeniu nie jest on przyjaźnią; 2) oprócz tego tekst Arystotelesa upoważnia nas do stwierdzenia, że - w niektórych przypadkach - philia [przyjaźń] przybiera postać nie tylko jakiegoś uczucia, ale również uczucia doznanego w sposób właściwy, uczucia dobrze pokierowanego, to znaczy, i innymi słowy - jest cnotąa $a^{45}$.

Jasne więc jest, że przyjaźń, według Arystotelesa, tylko w niektórych przypadkach jest cnotą, zawsze natomiast jest uczuciem ${ }^{46}$. Władysław Tatarkiewicz $w$ artykule z 1931 roku, poświęconym trzem etykom Arystotelesa zarysowanym w Etyce

44 Por. A. Fermani, L'etica di Aristotele, s. 88-89.

45 Tamże, s. 91.

46 To oznacza, że spośród omówionych wcześniej trzech Arystotelesowskich typów albo form przyjaźni (zob. 3.4.1.), mających za przedmiot korzyść, przyjemność i cnotę, przyjaźń według cnoty stanowi tylko jedną z możliwych przyjaźni, a nie jedyną, chociaż jest „pierwszą przyjaźnią”. Według J. Annas, Plato and Aristotle on Friendship and Altruism, „Mind” LXXXVI (1977), s. 553, Arystoteles przesadnie rozszerza pojęcie przyjaźni. Czyni to oczywiście w polemice ze swoim mistrzem, Platonem - por. Etyka eudemejska, VII, 2, 1236 b 11-26: „I ludzie źli mogą być sobie nawzajem przyjaciółmi tak ze względu na pożytek, jak i ze względu na przyjemność. Niektórzy utrzymują, że nie są oni przyjaciółmi, ponieważ nie spotyka się wśród nich owej "pierwszej« przyjaźni [ ...]. Ale to jest przyjaźń [zawarta ze względu na korzyść i ze względu na przyjemność], jak powiedzieliśmy, chociaż nie ta pierwsza, lecz na niej się opiera. Stąd używanie określenia »przyjaciel wyłącznie w tym sensie [pierwszej przyjaźni] zadaje kłam zaobserwowanym faktom i zmusza do wypowiadania paradoksów. I jest niemoźliwe sprowadzić wszystkie formy przyjaźni do jednej definicji. Pozostaje więc przyjąć taki pogląd, że istnieje tylko jedna przyjaźń - ta pierwsza; ale $z$ drugiej strony znajdują się wszystkie jej formy $i$ ani nie jest tak, że są one podobne $z$ nazwy i że zachodzą między nimi przypadkowe stosunki, ani że nie podpadają pod jeden rodzaj, lecz raczej - zestawia się je z jedną rzeczą". 
nikomachejskiej („etyka umiaru”, księgi I-VII; „etyka przyjaźni”, księgi VIII-IX; „etyka kontemplacji”, księga X), które wyrażają trzy różne stanowiska etyczne wielkiego Stagiryty, mianowicie „umiar”, „przyjaźń” i „kontemplacje” - idzie jeszcze dalej w ocenie jego poglądów na temat przyjaźni i mówi:

Rozważania Arystotelesa o przyjaźni są zupełnie odmiennej natury od tych, które traktują o cnotach [chodzi o „etykę umiaru”]. Nie ma tu zasady naczelnej umiaru, nie ma racjonalnego opanowania życia, nie ma cnót w określonym przez Arystotelesa znaczeniu; jest tylko więź uczuciowa, ale więź ta zastępuje cnoty ${ }^{47}$.

Skoro w przyjaźni - jak twierdzi Tatarkiewicz - więź uczuciowa jest w stanie zastąpić cnoty, to znaczy, że uczucia odgrywają w niej zupełnie inną rolę niż w pozostałych cnotach etycznych. Nie mają statusu jedynie instynktownych emocji i jakichś irracjonalnych sił wegetatywnej części duszy. Nie są zwykłymi ancillea rationis, które po prostu winny dać posłuch rozumowi i mechanicznie mu się podporządkować. W przyjaźni doskonałej, która jeszcze bardziej niż sprawiedliwość jest cnotą na wskroś relacyjną, przyjaciele nie są skierowani ku sobie samym, ku własnym uczuciom, które mieliby analizować rozumem, a wolą dokonywać korekty ich nadmiaru lub niedostatku. Przyjaciele w ogóle nie zmierzają do samokontroli, nie są zracjonalizowanymi perfekcjonistami, którym by zależało na własnym samodoskonaleniu. Przeciwnie, są całkowicie otwarci na siebie nawzajem. Właśnie uczuciami swoimi są wystawieni jeden na drugiego i za ich pomocą poznają siebie wzajemnie. Poznają lepiej, niż byliby to w stanie uczynić każdy z osobna na drodze jedynie intelektualnych rozmyślań o sobie.

Chodzi tu oczywiście o poznanie jednocześnie intelektualne i afektywne, dokonujące się choćby przez niespodziewane reakcje uczuciowe, wywołujące czasami wypieki na twarzy, a jednak pozwalające dostrzec i wychwycić najdrobniejsze nawet szczegóły życia (etycznego) przyjaciół i łączącej ich relacji. Przyjaciele nie przekonują się do cnoty i dobrego życia jedynie za pomocą racjonalnych argumentów, lecz o wiele bardziej przez wspólne doświadczenie, zdobywane długim przebywaniem ze sobą i cierpliwym zestrajaniem swoich uczuć, myśli i czynów.

Samo tylko intelektualne poznanie drugiej osoby nie mogłoby objąc tego wszystkiego, czego dostarcza zażyłość przyjaźni. Poznanie przez przyjaźń kierowane jest przyjemnością przebywania w towarzystwie drugiego, uczuciami uwagi i czułości, rozwiniętymi przez częstotliwość spotkań i wspólną historię. Niejednokrotnie uczucie przykuwa uwagę i otwiera spojrzenie na to, co inaczej pozostałoby

47 W. Tatarkiewicz, Trzy etyki: studium z Arystotelesa, w: tenże, Dobro i oczywistość, Lublin 1989, s. 217 (podkreślenia A. W.). 
w ukryciu. Jedynie dzięki tego rodzaju zdolności postrzegania i reagowania na niuanse życia drugich możliwe staje się wi i ze n ie charakteru, które leży u podstaw tegoż poznania ${ }^{48}$.

Arystoteles mówi również, że prawdziwi przyjaciele „nie odgrywają komedii przed sobą $[\ldots]$, nie ukrywają nawet swych własnych wad $[\ldots]$, nie wstydzą się siebie" 49 . Tego typu gra uczuciami byłaby zaprzeczeniem samego rdzenia ich relacji.

Nie oznacza to jednak, że uczucia, które wiążą przyjaciół i pomagają im się wzajemnie poznać, są automatycznie cnotą. Same w sobie nigdy nie są i nie mogą być cnotą ${ }^{50}$. Jednakże w przypadku prawdziwych przyjaciół cnota może być i faktycznie jest uczuciem, a ściśle - uczuciem dobrze przeżytym, wymierzonym dokładnie pomiędzy wadliwymi skrajnościami ${ }^{51}$. W tym i tylko w tym wypadku cnota przyjaźni i dobrze wymierzone uczucie przyjaźni stanowią jedną i tę samą rzeczywistość.

Mając na uwadze tę rzeczywistość, Arystoteles mówi o człowieku „moralnie doskonałym”, dla którego „rzeczy bezwzględnie dobre są dobrymi i bezwzględnie piękne pięknymi" "52. Mówi o człowieku określanym w kulturze greckiej mianem kaloskagathos ${ }^{53}$, „piękny i doskonały moralnie”, a utożsamianym ze spoudaios ${ }^{54}$, „człowiekiem szlachetnym". Taki człowiek w każdej chwili i w każdej sytuacji stanowił żywe kryterium i namacalny wzorzec autentycznego postępowania moralnego.

Takiego człowieka ma na uwadze również św. Grzegorz z Nazjanzu w swojej słynnej mowie pochwalnej na cześć św. Bazylego Wielkiego. Przyjaźń, która wskrzesiła w nich „,iskrę płomiennego uczucia i związała wzajemną miłością”, nie tylko kazała im „szukać właściwej filozofii życia”, polegającej na „wzajemnym doskonaleniu się w cnocie", ale sprawiła, że obaj, wychowani w tej samej greckiej kulturze, w pewnym momencie stali się „dla siebie [nawzajem] wzorem i normą, za pomocą których rozróżnia się dobro i zło" 55 .

Takim człowiekiem, chociaż wychowała się w zupełnie innej kulturze, była dla swoich sióstr w klasztorze św. Teresa od Jezusa.

48 M. Nussbaum, La fragilità del bene. Fortuna ed etica nella tragedia e nella filosofia greca, Bologna 2011, s. 655.

49 Retoryka, II, 1381 b 29-31.

50 Por. Etyka nikomachejska, II, 5, 1105 b 28-29: „Do namiętności nie należą ani cnoty, ani wady etyczne".

51 Por. A. Fermani, L'etica di Aristotele, s. 163-164.

52 Etyka wielka, II, 9, 1207 b 32.

53 Por. Etyka eudemejska, VIII, 3, 1249 a 16.

54 Por. Etyka wielka, II, 9, 1207 b 23.

55 Grzegorz z Nazjanzu, Mowa 43, 21, w: Liturgia godzin. Codzienna modlitwa Ludu Bożego, t. I, Pallottinum 1982, s. 1030. 


\subsubsection{Przyjaźn jako uczucie według św. Teresy od Jezusa}

Kwestia przyjaźni jako uczucia od samego dzieciństwa jest Teresie wyjątkowo bliska. Z jednej strony jest ona świadoma bycia sowicie obdarowaną przez naturę/ Boga - w tym wielkiego bogactwa swoich emocji, uczuć, namiętności - a z drugiej ma poczucie chwiejności coraz to nowych związków przyjaźni, w jakie mimowolnie wchodzi ${ }^{56}$. Długie lata zmagań z żywiołowością własnej natury i ogromnej pracy nad charakterem, możliwej także dzięki pomocy świattych kierowników duchowych (letrados), którzy uczą ją nazywać rzeczy po imieniu, a przede wszystkim osobiste spotkanie z Pierwszym Przyjacielem, z czasem przynoszą oczekiwane owoce. Teresa bez najmniejszych złudzeń coraz precyzyjniej odróżnia uczucia (namiętności) od właściwej cnoty.

W Księdze życia, wspominając swoje dzieciństwo, pisze: „Żal mi się robi, gdy wspomnę na dobre skłonności, jakimi mię Pan był obdarzył, a jak zły czyniłam z nich użytek” $(1,3)$. I dalej: „Smuci mię teraz i boli myśl i wspomnienie o tym, co było powodem, iż nie wytrwałam $w$ tych dobrych pragnieniach, jakie miałam z początku" $(1,7)$. Albo inny aspekt: „W chęci dogodzenia drugim, choćby z przykrością dla siebie, nie znałam miary. I tak, co w drugich byłoby cnotą, we mnie było nagannym zapędem, bo często w swojej usłużności daleko wykraczałam z granic roztropności" $(3,4)$. I jeszcze jedno świadectwo z późniejszego okresu jej życia: „Dobrze widzę, że to, iż jestem wdzięczna, nie pochodzi u mnie z doskonałości [cnoty]. Musi to wypływać z natury, że można mnie przekupić jedną sardynką" ${ }^{57}$.

Już tych kilka tylko luźnych zapisków uwidacznia doskonałe poznanie samej siebie przez Teresę, a jednocześnie dobrą znajomość podstawowych dystynkcji stosowanych także w filozofii etyki. Teresa wie, czym jest namiętność, pragnienie, natura, skłonność, a czym cnota, roztropność, wytrwałość, umiar i jaka jest różnica między pierwszymi a drugimi. Wie, że cnota wymaga od człowieka świadomej i cierpliwej pracy nad własnymi uczuciami i zmierza do ukształtowania w sobie niejako „drugiej natury", nie dualistycznie jednak, w kolizji z pierwszą, lecz na zasadzie jej świadomego rozwoju i wychowania w kierunku dobra.

Ta wiedza, zaczerpnięta z własnego doświadczenia, ale doskonale harmonizująca z racjami rozumowymi, jakie w swoich pismach wyłuszczyli choćby Platon i Arystoteles, uprawnia Teresę do podjęcia się zadania kształtowania uczuć innych. Realizuje je między innymi w Drodze doskonatości, w rozdziałach 4-7, gdzie zgłębia Jezusowe przykazanie miłości bliźniego. Przedstawia tam swoje rozumienie stosunku do uczuć w relacjach przyjaźni.

56 Temat ten w odniesieniu do życia św. Teresy został szeroko omówiony w drugim rozdziale niniejszego studium, zatytułowanym Od wielu przyjaciót do Pierwszego Przyjaciela, „Itinera Spiritualia” IX (2016), s. 122-147.

57 List 264, do m. Marii od św. Józefa w Sewilli, Avila, wrzesień 1578. 
Nie czyni tego jednak na drodze teoretycznej, w wielkim monologu jak Arystoteles, lecz raczej jak Platon i jak doświadczony pedagog - to znaczy wchodzi w bezpośredni kontakt ze swoimi rozmówczyniami i podejmuje z nimi żywy dialog. Ponieważ ma świadomość, że Jezusowe przykazanie miłości nie zmierza do wpojenia uczniom jakichś określonych postaw ${ }^{58}$, sama również tego nie czyni w stosunku do swoich sióstr w Karmelu. Nie narzuca im ani nawet nie proponuje kazuistycznie żadnych gotowych wzorców życiowych, żadnych postaw, choćby najwznioślejszych. Zwraca natomiast uwagę właśnie na uczucia, które stanowią fundament i istotę ludzkiego życia. Zdaje sobie bowiem sprawę, że wypracowanie przez człowieka konkretnych postaw zależy od tego, co ten człowiek zrobi ze swoimi uczuciami. Teresa - pedagog-przyjaciel - pomaga siostrom ukierunkować uczucia na dobro, na na jw yżs ze Dobro.

Dla prześledzenia pedagogii Teresy warto przyjrzeć się wielorakim znaczeniom, jakie nadaje ona słowu „namiętność” (pasión). W jej rozumieniu jest ono intensywnym odcieniem uczucia, a więc jest wyrażeniem, k tóre doskonale nadaje się do analizy rzeczywistości przyjaźni. W Drodze doskonatości słowo to pojawia się jedynie w rozdziałach 4-7, ale za to aż pięć razy. Najpierw czterokrotnie występuje w formie rzeczownikowej (pasión), a następnie w formie przymiotnikowej (apasionado). Ważne również, że za każdym razem pojawia się w powiązaniu z wzajemną miłością i przyjaźnią ${ }^{59}$. W prawdzie w tych samych rozdziałach jeden raz występuje jeszcze synonimiczne słowo afición (zamiłowanie, skłonność, pociąg), trzykrotnie przymiotnik aficionado i czterokrotnie czasownik aficionar, ale zawsze w formie bardziej ogólnej, niekoniecznie w odniesieniu do wzajemnej miłości/przyjaźni, i nie ma tej samej siły wyrazu co „namiętność”. Tym właśnie słowem Teresa „rozgrywa” cały dramat przyjaźni, ukazując szerokie spektrum niezwykle delikatnych zagadnień uczuciowych, których nie moźna nie wziąć pod uwagę, gdy rozważa się ten temat. Przyglądnijmy się każdemu użyciu tego słowa z osobna.

Po raz pierwszy Teresa mówi o namiętności w rozdziale 4. Jej wypowiedź jest bardzo kategoryczna i zdaje się nie pozostawiać najmniejszych złudzeń co do miejsca i roli tego uczucia w prawdziwej miłości przyjaźni: „Gdzie jest miłość prawdziwa, dążąca do miłości Bożej, tam wola nie powoduje się żadną namiętnością, ale raczej jedna [siostra] drugiej [siostrze] stara się być pomocą ku pokonaniu wszelkich namiętności” $(4,6)$.

W tym samym rozdziale, po dokonaniu zasadniczego rozróżnienia na dwa rodzaje miłości, mianowicie: jedną doskonałą, czystą, duchową, a drugą „również duchową, ale z domieszką przyrodzonej zmysłowości i słabości” $(4,12)$ (por. 3.4.2.), Teresa po raz drugi wspomina o namiętności. Wytycza sobie bardzo radykalny pro-

58 Por. W. Janusiewicz, La sapienza è amicizia..., s. 227.

59 Warto zauważyć, że we wszystkich pismach św. Teresy rzeczownik pasión występuje zaledwie 39 razy (nie licząc słowa Pasión odnoszącego się do Męki Jezusa), natomiast przymiotnik apasionado dziewiećc razy. 
gram nauczania na temat prawdziwej miłości przyjaźni, w którym powtarza myśl wyrażoną już w pierwszym zdaniu: „Chcę teraz mówić o miłości duchowej, wolnej od wszelkiej namiętności, bo gdy ta się przyplącze, rozstraja z gruntu wewnętrzną harmonię duszy" $(4,13)$.

Jak wynika z powyższych dwóch cytatów, miłość prawdziwa, tzn. duchowa, doskonała, czysta, w całości jest ukierunkowana na Boga i - według słów Teresy - jest też „wolna od wszelkiej namiętności”, „nie powoduje się żadną namiętnością”, co więcej, dąży do „pokonania wszelkich namiętności”, gdyż one „rozstrajają z gruntu wewnętrzną harmonię duszy".

Warto zauważyć, że tego rodzaju stwierdzenia, wyrwane z szerszego kontekstu, zbliżają Teresę z jednej strony do stanowiska stoików, według których namiętności zaćmiewają działanie rozumu i człowiek za wszelką cenę musi je wykorzenić, gdyż inaczej nie osiągnie wymarzonego stanu apatii i szczęścia ${ }^{60}$, a z drugiej do stanowiska nowożytnej psychologii, która „pojęła uczucia jako stany wyłącznie subiektywnepowodowane przez »przyczyny «ewnętrzne, które nie wchodzą jednak do definicji określonych uczuć jako ich jakości” ${ }^{1}$. Sugerują również, że terezjańska miłość duchowa jest oderwana od ciała i jego doznań, a więc jest oparta na pewnym dualizmie antropologicznym: dusza-ciało.

W rzeczy samej, Teresa zbliża się do stoików, ale bynajmniej nie ze swoim rozumieniem namiętności i związanej z nią apathei, lecz raczej w trosce o uwolnienie człowieka od wszelkich iluzji i skłonienie go do kierowania się rozumem. Ma również nowożytną wrażliwość na psychologię, ale jej widzenie rzeczywistości nie sprowadza się do wymiaru biologicznego, lecz otwiera na wymiar metafizyczny (i teologiczny). Promowana zaś przez nią miłość duchowa - jak jawi się ona w kolejnych jej wypo-

60 Według Chryzypa, namiętności są błędami samego rozumu, a tym samym dezorganizują życie i są przyczyną wszystkich nieszczęść. W związku z tym Zenon twierdził, że nie ma sensu ich łagodzenie czy oczyszczanie, lecz naleźy je całkowicie usunąć i zniszczyć. Człowiek cnotliwy jest apathes, to znaczy niewzruszony, nigdy się nie unosi i nie ulega wzburzeniu. Od prawdziwego mędrca wymaga się apathei, tzn. wolności od jakiejkolwiek namiętności. Cnota w ujęciu stoików ma charakter wybitnie rozumowy. Szczęście jest apatią, beznamiętnością. Por. Diogenes LaETRIos, Żywoty i poglady stynnych filozofów, VII, 117, Warszawa 2012, s. 422; G. REALE, Historia filozofii starożytnej, t. III, Lublin 1999, s. 394-436. Warto tu dodać, że św. Teresa, która w przytoczonych wyżej wypowiedziach sama zdaje się zbliżać do pozycji stoickich, w szczególności do Seneki, swego przyjaciela św. Jana od Krzyża zwykła nazywać „moim małym Seneką”. Por. również list skierowany do drugiego przyjaciela, o. Hieronima Graciana, w którym pisze: „Mówi bardzo zadowolony Seneka [o. Jan od Krzyża], że w swoim przełożonym [o. Gracianie] znalazł więcej, niż mógł się spodziewać" ( List 92, do o. Hieronima Graciana w Toledo, Sewilla, połowa października 1575, n. 4). Zaznaczmy jeszcze, że w epoce renesansu Seneka był jednym z najbardziej popularnych i cenionych filozofów starożytności.

61 R. Spaemann, Szczéście a życzliwość, s. 56; Spaemann twierdzi jeszcze, że „w wieku siedemnastym jedynie wielki Arnauld zauważył, że przedmioty uczuć nie mają się do nich tak jak causa efficiens, lecz jak causa formalis. Nie są »przyczynami«, lecz »treścią uczuć” (tamże). Czy tę różnicę widziała św. Teresa i czy dostrzegali ją także inni przedstawiciele XVI wieku, który stanowił próg nowożytności i był już zafascynowany odkryciami nowożytnej psychologii oraz oddany introspekcji? 
wiedziach - jest równocześnie miłością przeżywaną cieleśnie i angażującą wszystkie ludzkie namiętności.

Święta daje temu wyraz w rozdziałach 6 i 7 Drogi doskonałości. W dalszym ciągu mówi w nich o miłości czysto duchowej, gdyż uważa, że jeżeli dobrze „przypatrzymy się tej cnocie, to tym samym zachęcimy się do jej praktykowania" $(6,1)$, jednak czyni to już w sposób bardziej zróżnicowany niż w rozdziale 4 . Tam bowiem jej celem było „rozprawienie się” z przywiązaniami uczuciowymi, które zagrażają budowaniu prawdziwych więzi przyjaźni, opartych na niezależności osób. Musiała więc użyć języka bardziej kategorycznego, stanowczego i pouczającego; musiała wyrazić rzeczywistość niejako czarno-białą. Chodziło wszak o jednoznaczne odcięcie się od tego, co mogłoby zniszczyć przyjaźń. Teraz natomiast jej wypowiedzi są bogatsze kolorystycznie, a jednocześnie bardziej stonowane i koncyliacyjne. Teresa głośno „zastanawia się" nad wieloma kwestiami, a nawet wyraża wątpliwości. Chce mówić o miłości czysto duchowej, ale pokornie przyznaje: „nie wiem, o ile ona jest duchowa i co w niej jest zmysłowego, a co duchowego" $(6,2)$.

Dialektyka miłości duchowej a miłości zmysłowej (namiętnej) staje się przedmiotem dalszego dialogu między nią a siostrami. Dialog ten jest coraz częstszy, a przede wszystkim coraz bardziej pasjonujaccy. Teresa wyczuwa bowiem zastrzeżenia, jakie w sercach sióstr może budzić jej koncepcja miłości przyjaźni i uporczywe naleganie na miłość czysto duchową; domyśla się ich obaw, dotyczących niebezpieczeństwa zdewaluowania wymiaru cielesnego, a konkretnie - namiętności, tak jak się je przeżywa w konkretnych relacjach międzyludzkich. „Powiecie może: „Czyż takie dusze nikogo i niczego nie kochają i kochać nie umieją, tylko samego Boga?" (6, 5-7). I jeżeli kochają tylko Boga, to ,jaki pożytek mogą mieć z pragnienia miłości?” (tamże). Trzeba przyznać, że są to pytania osób mocno stąpających po ziemi.

Odpowiadając na tego rodzaju wątpliwości i zastrzeżenia, własne i sióstr, Teresa wypowiada kolejne zdanie, w którym, po raz trzeci już w rozdziałach 4-7 Drogi doskonatości, pojawia się słowo „namiętność”. Tym razem jednak występuje ono w znaczeniu wybitnie pozytywnym. Teresa już nie wyraża, tak jak to czyniła w rozdziale 4 , negatywnych sądów na temat namiętności i nie wzywa sióstr do eliminowania ich z życia, ale przyjmuje je, oczyszcza i włącza w krwiobieg swojej duchowej miłości. W jej całościowej wizji miłości-przyjaźni namiętności stają się siłą dynamizującą tę relację. A ponieważ Teresa ma przed oczyma żywe wzory takiej zaangażowanej, namiętnej miłości, więc z pełnym przekonaniem może odpowiedzieć siostrom na ich pytania i wątpliwości: „Owszem, upewniam was, [takie dusze] kochają nierównie mocniej, goręcej [w oryginale pasión, a dokładniej: con más pasión - z większą pasją, $\mathrm{z}$ większą namiętnością, wszystkimi uczuciami] i bardziej owocną miłością niż inni” $(6,7)$. I na wszelki wypadek dodaje: „Tylko taka miłość [tj. namiętna] godna jest tej nazwy, a wszelkie inne niskie przywiązania przywłaszczają sobie tylko miano miłości" (tamże). 
Z powyższego tekstu wynika, że św. Teresa, w przeciwieństwie do stoików, nie tylko nie eliminuje namiętności z relacji przyjaźni, ale chce, żeby w życiu jej sióstr-przyjaciółek było ich jak najwięcej: mają miłować się wzajemnie con más pasión. $Z$ drugiej jednak strony, w żaden sposób nie wpisuje się w nowożytne tendencje biologistyczne i nie traktuje owego con más pasión płasko, jednowymiarowo. Za Arystotelesem, a przede wszystkim za św. Tomaszem z Akwinu ${ }^{62}$, który przyjął i pogłębił myśl starożytnego Filozofa (tak Akwinata prawie zawsze nazywa Arystotelesa), Święta precyzyjnie rozróżnia namiętności, które mają swoje źródło w zmysłach, i te mające początek w ludzkim umyśle. A chociaż nie rozdziela w człowieku tych dwóch sfer, to jednak zdecydowanie uwydatnia potencjał drzemiacy w sferze umysłowej, to znaczy w rozumie i woli, i ostatecznie tutaj widzi pierwsze źródło i całe ognisko ludzkich namiętności.

Słowo „namiętność” nie jest tu użyte w sensie metaforycznym, jakby jego właściwe znaczenie miało się odnosić tylko do sfery zmysłowej. Św. Teresa ma rzeczywiście na uwadze namiętność umysłową, którą św. Tomasz nazwał passio animalis, w odróżnieniu od passio camalis ${ }^{63}$. W jej rozumieniu zaczyna się ona w duszy człowieka, a kończy w jego ciele ${ }^{64}$. Teresa ukazuje ją na przykładzie osób, które kochają miłością bezinteresowną. Nie zatrzymują się one na postrzeganiu zmysłowym i przemijających przedmiotach (przymiotach), lecz przenikliwym wzrokiem swego rozumu szukają w duszach swoich przyjaciół dóbr trwałych, wiecznych, osobowych. Kiedy tylko dostrzega w nich jakieś rzeczywiste dobro, natychmiast wolą swoją skłaniają się ku niemu w taki sposób, że przekształcają je w dobro dla przyjaciół, angażując w to przedsięwzięcie również całą swoją sferę cielesną i zmysłową.

„Może zapytacie jeszcze: jeśli te dusze [kochające miłością doskonałą ] nie kochają nic z tego, co podpada pod zmysły, cóż zatem kochają?” (Dv 6, 8). Stawiając to pro-

62 Por. STh I, q. 20, a. 1, ad 1-2; Tomasz z Akwinu, Quaestiones disputatae de veritate, q. 25-28.

63 Tenże, Quaestiones disputatae de veritate, q. 26. I. Sciuto, jeden z komentatorów tej kwestii Akwinaty, pisze: „De veritate uwydatnia [...] rozróżnienie, które jest przemilczane w Sumie, a które jest bardzo znaczące: mówi się o namiętności, że jest corporalis, gdy rozumie się, że dusza jest zjednoczona z ciałem ut forma, tak że namiętność zaczyna się w ciele, a kończy w duszy, np. w przypadku zranienia; mówi się natomiast o namiętności, że jest animalis, gdy myśli się o jedności duszy ut motor, tak że ruch zaczyna się od duszy, a zmierza ku ciału, np. w przypadku gniewu albo lęku, i ta wydaje się być namiętnością w sensie właściwym”. I. Scruto, Le passioni dell'anima nel pensiero di Tommaso d'Aquino, w: Anima e corpo nella cultura medievale. Atti del V Convegno di studi della Società Italiana per lo Studio del Pensiero Medievale, Venezia 25-28 sett. 1995, red. C. Casagrande, S. Vecchio, Firenze 1999, s. 78.

64 Interesujące, że św. Teresa wskazuje na podobną dynamikę, jakkolwiek na poziomie znacznie wyższym, bo teologicznym, gdy mówi o źródle tzw. smaków, jakich można doświadczyć na modlitwie. Używa nawet podobnego sformułowania: „Te smaki poczynają się w Bogu, a kończą w nas”. I precyzuje: "także cały zewnętrzny człowiek [czyli ciało] cieszy się tym smakiem i tą słodkością" (T IV, 2, 2-4). W tym kontekście Swięta mówi jeszcze o drugim źródle, jakkolwiek nie tak doskonałym jak pierwsze, z którego pochodzą „pociechy”. Jest nim... ludzki umysł. Analogia między tymi źródłami wydaje się bardzo trafna. 
wokacyjne pytanie, Teresa chce, by siostry podjęły się niełatwego zadania przejścia od tego, co zmysłowe, do tego, co duchowe. Chodzi jej o wielki intelektualny trud, który Platon nazwał „drugim żeglowaniem”, czyli przejściem od tego, co widzialne, do tego, co niewidzialne, a jednak inteligibilne; chodzi jej o trud także egzystencjalny, angażujący człowieka również cieleśnie. Święta pomaga siostrom zrozumieć te rzeczy:

Kochają one to, co widzą i miłują, co słyszą, tylko że to, co one widzą i słyszą, jest nieprzemijające. Pomijając ciało, wzrokiem duchowym sięgają do duszy tego, kogo miłują, i patrzą, czy jest w niej co godnego miłości; jeśli znajdą w niej choćby tylko jaki zaczyn dobra i cnoty, choćby jaką skłonność i usposobienie wewnętrzne [principio o disposición], z którego może da się wydobyć miłość Bożą, tak jak złoto dobywa się z kopalni, wtedy dla dobra tej duszy nie szczędzą żadnego trudu, i nie ma takiej ofiary, której by ochotnie z siebie nie uczyniły dla pozyskania jej Bogu. Chcą bowiem i pragną miłować ją (tamże).

Ukierunkowanie na dobro przyjaciela wydaje się stanowić kwintesencję nauki św. Teresy na temat przyjaźni jako uczucia. W porównaniu z nowożytną tendencją do koncentrowania się na sferze zmysłowej, w której przyjaźń zostaje sprowadzona do mglistych sentymentów i wyczerpuje się wraz z ich doznaniem, Teresa idzie dalej (by nie powiedzieć: w przeciwnym kierunku). Święta pokazuje, że w miłości przyjaźni nie chodzi o patrzenie w siebie i przeżywanie swoich uczuć. Nie chodzi nawet o ich kontrolowanie pod szlachetnym pretekstem budowania w sobie prawidłowych postaw lub ćwiczenia się w rzekomej cnocie. W relacji przyjaźni chodzi po prostu o ukierunkowanie na dobro, które jako jedyne ma moc naturalnego poruszenia wszystkich uczuć i skłonienia ich do autentycznej miłości. W tym sensie przyjaźń ma również charakter praktyczny - jest budowana poprzez konkretne czyny miłości.

W serii krótkich, następujących tuż po sobie zdań Święta na różne sposoby powtarza właściwie jedną i tę samą myśl: chodzi o właściwe ukierunkowanie w miłości przyjaźni i potwierdzenie tego kierunku konkretnymi czynami miłości:

Wszelkie pragnienie tego, aby nas kochano, jest w gruncie dowodem wielkiego zaślepienia (Dv 6, 5).

Gdy pragniemy, aby nas kochano, zawsze w tym szukamy jakiegoś interesu własnego, pożytku czy przyjemności (Dv 6, 6).

Dusze wyższym świattem oświecone nie troszczą się o to, czy je k to kocha czy nie (Dv 6,7).

Kochają one nierównie mocniej, goręcej i bardziej owocną miłością niż inni. Jest to miłość szlachetna, zawsze ochotna dawać raczej, niż brać (tamże).

Warte podkreślenia jest jeszcze jedno zdanie, w którym Teresa po raz czwarty w rozdziałach 4-7 Drogi doskonałości używa słowa „namiętność” - i ponownie w sensie 
pozytywnym. Ma mianowicie na uwadze czynną miłość, która „pracuje z świętą namiętnością [pasión] nad tym, aby dusza [przyjaciela] była przez Boga ukochana, bo wie, że inaczej na trwałe wypadnie z tej życzliwości wobec niej" (6,9). Życzliwość, jak już mówiliśmy, jeszcze nie jest przyjaźnią, ale jest jej warunkiem. By to ogólne uczucie mogło się przekształcić w uczucie konkretne i stać się przyjaźnią trwałą, potrzebna jest „praca ze świętą namiętnością” nad poszerzeniem perspektywy dobra o wymiar nieskończony - Boga.

Punktem kulminacyjnym wywodów Teresy na temat przyjaźni jako uczucia jest wypowiedź, w której po raz piąty w omawianych rozdziałach sięga po słowo „namiętność" (pasión), a właściwie po jego przymiotnikową formę: apasionado (namiętny, roznamiętniony, rozmiłowany, rozpalony, rozkochany), by jeszcze bardziej uwydatnić stopień wyższy czynnej strony miłości przyjaźni. Nie ogranicza się przy tym do jakiegoś ogólnego stwierdzenia, lecz szczegółowo opisuje i wyjaśnia, na czym w praktyce tego rodzaju uczucie (namiętność) miłości polega. Święta z pełnym znawstwem rzeczy odwołuje się tu do dwóch namiętności, które przez obie tradycje, klasyczną i chrześcijańską, uważane były za podstawowe namiętności pożądawcze, mianowiciedoradości i bólu.

Dziwna to zaiste gorącość tej miłości [ apasionado amor]. Ile ona łez kosztuje, ile pokut i umartwień, ile modlitw i usilnego polecania się modlitwom każdego, kto ją przyczyną swoją do Pana wspomóc może! Jaka radość, gdy w tej duszy, którą miłuje, ujrzy jaki postęp ku lepszemu! Jaka boleść, gdy spostrzeże, że ta dusza ukochana choćby tylko o jeden krok cofnęła się wstecz! Boleść ta niepocieszona zatruwa jej życie, nie może spożyć kęsa chleba, nie może zażyć chwili spoczynku nocnego bez tej troski ciagle dręczącej, bez tej trwogi wszędzie jej towarzyszącej, że ta droga dusza zginąć może (Dv 7,1).

W opisanej tu przez Teresę przyjaźni jako uczuciu, gdy osoby kochają „w Bogu i dla Boga" (tamże), nie ma miejsca na samokontrolę uczuć, rozmyślanie nad nimi, selekcjonowanie ich i ewentualne thumienie. Wszystkie uczucia, poczynając od najgłębszych, pozostają w służbie dobra przyjaciela.

\subsection{Przyjaźń a miłość w ujęciu Arystotelesa i św. Teresy od Jezusa}

Ważna w tym miejscu wydaje się uwaga, że w dotychczasowych refleksjach kluczowe słowa na określenie przyjaźni używane były bez rygorystycznego trzymania się ich ścisłych znaczeń. $Z$ dużą swobodą i zamiennie, odwołując się raczej do powszechnej intuicji, raz stosowaliśmy słowo „miłość”, innym razem „przyjaźń”, a kiedy indziej jeszcze „miłość erotyczna” albo „miłość przyjaźni” (nie licząc takich określeń, 
jak „miłość doskonała”, „przyjaźń według cnoty” itd. $)^{65}$. Ta swoboda widoczna jest szczególnie w odniesieniu do myśli i idei wyrażonych przez św. Teresę od Jezusa, która zresztą nie pozwoliłaby na zamknięcie wielkich pragnień swojego kochającego serca w jakichkolwiek sztywnych pojęciach racjonalnych. A ponadto celem studium nie były badania filologiczne, lecz filozoficzne przybliżenie rzeczywistości przyjaźni oraz zwrócenie uwagi na podobieństwa i różnice w jej pojmowaniu przez Arystotelesa i św. Teresę.

Słusznie jednak zauważono, że „niemal wszyscy filozofowie piszący o przyjaźni, w tym także Grecy, mieli coś do powiedzenia na temat relacji między przyjaźnią a miłością. Co nie oznacza, że któremukolwiek z nich udało się w pełni rozjaśnić tę kwestię, albo choćby wprowadzić tu jakieś trwałe i precyzyjne rozróżnienia" ${ }^{66}$. Pierwsza uwaga dotyczy również Arystotelesa i św. Teresy od Jezusa, dla których pojęcia te nie były jednoznaczne, ale wysiłek, jaki w tej sprawie podjęli, dopinguje badaczy do dalszego eksplorowania rzeczywistości przyjaźni. Nie zniechęca w tym zadaniu fakt, że dzisiaj, na skutek gwałtownych przemian kulturowych zachodzących w naszej cywilizacji, kwestia relacji między przyjaźnią a miłością jeszcze bardziej się skomplikowała. Główną tego przyczyną są zmiany w rozumieniu miłości, odwołującej się do greckiego erosa ${ }^{67}$. Podczas gdy dla Greków, szczególnie Platona, stanowiła ona pozytywną siłę zdolną uwolnić człowieka z niewoli namiętności i uczynić z niego filozofa, tj. przyjaciela mądrości, poszukującego piękna, dobra i prawdy ${ }^{68}$, dzisiaj uległa ona degradacji, a samo pojęcie erosa nabrało znaczenia wybitnie pejoratywnego ${ }^{69}$. Eros, zamknięty w immanencji i pozbawiony wymiaru duchowego, został sprowadzony do zwykłego zmysłowego erotyzmu. Szerokim kręgom ludzi do tego stopnia kojarzy się on wyłącznie ze sferą cielesnych, naskórkowych doznań, że nie sposób o nim pisać bez dodatkowych wyjaśnień i zastrzeżeń, które pozwoliłyby uniknąć nieporozumień.

$\mathrm{Z}$ drugiej strony, nie można nie zauważyć, że $w$ dziejach włożono wiele wysitku w to, by ukazać prawdziwą wielkość erosa. Jednym z ostatnich i najbardziej udanych dokonań w tej materii jest encyklika Benedykta XVI Deus caritas est ${ }^{70}$. Papież,

65 Wymienione zbitki słowne - „miłość erotyczna”, „miłość przyjaźni”, , „miłość doskonała” i wiele podobnych - są owocem licznych, wielowiekowych i nieudanych do końca starań, by za pomocą kilku słów precyzyjnie oddać znaczenie jednego pojęcia greckiego. Por. P. Floreński, Filar i podpora prawdy. Próba teodycei prawosławnej w dwunastu listach, Warszawa 2009, s. 313-323. Tamże.

67 Por. A. FABRIS, I paradossi dell' amore - fra grecità, ebraismo e cristianesimo, Brescia 2000.

68 Por. G. KRüGER, Ragione e passione. L'essenza del pensiero platonico, Milano 1995; J.M. Rist, Eros e Psiche. Studi sulla filosofia di Platone, Plotino e Origene, Milano 1995; G. Reale, Eros. Dèmone mediatore e il gioco delle maschere nel Simposio di Platone, Milano 2005; L'Eros in Platone. Esposizioni filosofiche, confronti letterari, attualizzazioni pedagogiche, red. A. di Vita, Trento 2010; R. LuCA, Labirinti dell'Eros. Da Omero a Platone, Venezia 2017.

69 Por. M. Foucault, Historia seksualności, Warszawa 2000; H. Marcuse, Eros e civiltà, Torino 2001; M. Herer, Pochwata przyjaźni, Warszawa 2017.

70 BenedYKT XVI, Encyklika Deus caritas est do biskupów, prezbiterów i diakonów, do osób konsekrowanych i wszystkich wiernych świeckich o miłości chrześcijańskiej, Kraków 2006. 
w pełnej zgodzie z najlepszą tradycją chrześcijańską, z całą otwartością podejmuje greckie rozumienie erosa, zaznaczając jednocześnie, że „Eros potrzebuje dyscypliny, oczyszczenia, aby dać człowiekowi nie chwilową przyjemność, ale pewien przedsmak szczytu istnienia, tej szczęśliwości, do której dąży całe nasze istnienie" (nr 4). Ponad to nie przeciwstawia mu chrześcijańskiej agape, jak czynili to niektórzy autorzy jeszcze w pierwszej połowie XX wieku ${ }^{71}$, lecz szuka jedności obu tych idei ${ }^{72}$. Co więcej, w nawiązaniu do starodawnej chrześcijańskiej tradycji, nie waha się określić miłości samego Boga „jako Eros”, chociaż - powiada - jest ona „równocześnie także Agape" ( $\mathrm{nr} 7)^{73}$.

Przyjęte w niniejszym rozdziale ujęcie erosa wpisuje się oczywiście w ten ostatni nurt i, jak zobaczymy szczególnie w przypadku św. Teresy od Jezusa, jest otwarte na nadprzyrodzoną agape. Dzięki temu eros nie tylko sam dopełnia się w agape, ale w powiązaniu z nią zaczyna stanowić niezawodny punkt odniesienia dla kształtowania pojęcia przyjaźni (philia).

Pojęcia w dziejach nieustannie zmieniają znaczenie i żyją swoim własnym życiem. Nikt nie jest więc w stanie ani uchronić się przed negatywnym wpływem ich zniekształconych sensów, ani też rościć sobie pretensji do pełnej i ostatecznej ich wykładni. Perspektywa i dynamika, jaką przyjmują omawiani przez nas autorzy, jest jednak szczególnie interesująca. Warto się jej przyjrzeć.

\subsubsection{Przyjaźn a mitość w ujęciu Arystotelesa}

Ukierunkowanie na dobro, a dokładniej na dobro dla mnie - jak podkreślamy od początku tego rozdziału - stanowi niewątpliwie zasadniczy rys całej etyki Arystotelesa. Szukanie dobra przyjaciela ze względu na niego samego stanowi zaś cechę charakterystyczna jego koncepcji przyjaźni doskonałej, albo przyjaźni według cnoty. Z kolei podobieństwo w dobru jest tym elementem jego wizji przyjaźni, który zespala

71 Najbardziej emblematyczne dla takiego przeciwstawiającego ujęcia relacji agape-eros są dwa monumentalne dzieła z lat 30. ubiegłego stulecia: pierwsze szwedzkiego teologa protestanckiego: A. NygRen, Eros e Agape. La nozione cristiana dell'amore e le sue trasformazioni, Bologna 1990 (pierwsze szwedzkie wydanie z 1930); drugie francuskiego myśliciela: D. DE RougEMONT, L'amore e l'Occidente. Eros, morte abbandono nella letteratura europea, Milano 1998 (pierwsze francuskie wydanie z 1938). Por. również tego ostatniego: La persona e l'amore, Brescia 2018.

72 Por. komentarze do encykliki papieskiej oraz inne dzieła pisane w tym samym koncyliacyjnym duchu: G. Angelini, Eros e agape. Oltre l'alternativa, Milano 2006; A. Meluzzi, ErosAgape. Un unica forma d'amore, Roma 2006; M. Fasol, Eros greco e Amore cristiano. Furono davvero opposti?, Verona 2011; V. Possenti, I volti dell' amore, Genova 2015.

73 Papiez, nadając miłości Boga miano Erosa (oprócz Agape), przywołuje jedno tylko świadectwo z chrześcijańskiej starożytności, mianowicie: Pseudo-Dionizy Areopagita, O imionach Bożych, IV, 12-14. Cytowany jednak autor, żyący prawdopodobnie na przełomie V i VI wieku, sam powołuje się na świadectwo jeszcze wcześniejsze, bo z przełomu I i II wieku, i na słynne słowa Ignacego Antiocheńskiego: „Mój Eros [Chrystus] został ukrzyżowany” (List do Rzymian, 7, 2). Te same słowa św. Ignacego przywołuje w III wieku ORYGenes, Komentarz do „Pieśni nad pieśniami”, Prolog 4. 
przyjaciół ze sobą, sprawia, że stają się właśnie przyjaciółmi. Oznacza to, że wcześniej każdy z nich musiał zaprzyjaźnić się z samym dobrem, musiał stać się „dobry w bezwzględnym tego słowa znaczeniu i dobry dla przyjaciela" ${ }^{4}$. Jeszcze inaczej: przyjaźń $z$ dobrem każdego $z$ nich sprawia, że rozpoznają w tym dobru swoje wzajemne podobieństwo i dopiero opierając się na nim, dokonują wyboru prawdziwej przyjaźni. Ono jest gwarancją jej trwałości. Albo dokładniej: przyjaźn ich trwa dopóty, dopóki trwa ich podobieństwo w dobru.

Należy tu zrobić jeszcze jeden krok i podkreślić, że Arystoteles właśnie „na tym podobieństwie opiera różnicę między przyjaźnią a miłością, między philia a eros"75. Dla niego podstawową kategorią jest oczywiście przyjaźń ( philia). Niezmienność dobra i podobieństwo do niego sprawiają, że jest ona trwała, stabilna, zrównoważona i niezawodna. Miłość (eros) natomiast, ponieważ nie zasadza się na dobru i podobieństwie do niego, nie jest trwała, lecz ulotna.

Podkreślając podobieństwo trzech rodzajów przyjaźni (zawartych ze względu na cnotę, przyjemność, korzyść), Arystoteles dochodzi ostatecznie do wykazania różnicy między przyjaźnią a miłością:

Przyjaźń podyktowana względem na przyjemność jest podobna do poprzedniej [opartej na cnocie], bo i ludzie etycznie dzielni [cnotliwi] są sobie nawzajem mili, a podobnie też przyjaźń podyktowana względem na korzyść, bo i ludzie etycznie dzielni [cnotliwi] są też dla siebie nawzajem pożyteczni. Także spomiędzy tych rodzajów przyjaźni najtrwalsze są te, w których przyjaciele tego samego od siebie wzajemnie doznaja (np. rozkoszy), i to nie tylko tego samego, lecz także z tego samego źródła, jak to bywa we wzajemnym stosunku ludzi gładkich i dowcipnych, a nie jak w stosunku kochającego do ukochanego. Ci dwaj bowiem nie takiej samej doznają przyjemności, lecz pierwszego z nich cieszy widok ukochanego, tego zaś - względy, którymi go darzy kochający. A kiedy przeminie młodość, przemija niekiedy i miłość ich, bo pierwszego nie cieszy już widok ukochanego, ten zaś przestaje być przedmiotem zabiegów miłosnych; wiele jednak takich stosunków trwa nadal, jeśli dzięki przyzwyczajeniu powzięli wzajemnie upodobanie do swych charakterów, które są do siebie podobne ${ }^{76}$.

Trzeba zauważyć, że Arystoteles, w przeciwieństwie do Platona ${ }^{77}$, stosunkowo niewiele mówi na temat miłości erotycznej. Podczas gdy ten drugi zagląda do najgłębszych tajników ludzkiej duszy i odwołując się do jej struktury, skupia się na

74 Etyka nikomachejska, VIII, 3, 1156 b 13.

75 R. Caldarone, Eros decostruttore. Metafisica e desiderio in Aristotele, Genova 2001, s. 110, przyp. 58 (kursywa A. W.).

76 Etyka nikomachejska, VIII, 4, 1157 a 1-12.

77 Por. choćby jego dwa wielkie dialogi poświęcone tematowi erosa: Uczta i Fajdros. 
konstruowaniu państwa idealnego, zainteresowania Arystotelesa idą w kierunku organizowania realnej polis i budowania podstaw etycznych dobrego życia jej obywateli. W jego przekonaniu temu celowi najlepiej służy właśnie przyjaźn, natomiast miłość w jego wizji życia ludzkiego nie odgrywa znaczącej roli. „Miłość - pisze - jest jakby pewnym nadmiarem [hiperbole] przyjaźni; a to [jest możliwe tylko] w stosunku do jednego człowieka"78.

Ponadto Arystoteles doskonale pamięta, co Platon mówił w Fajdrosie na temat dążeń erosa do wyłączności i jego „dekonstrukcyjnych” zapędów ${ }^{79}$ :

Zakochany najlepiej wie, że miłośnik najwięcej by pragnął, aby jego kochankowi brakło dóbr najbliższych sercu, najżyczliwszych dusz, darów wprost od boga zesłanych. Niechby był sierotą, nie miał ojca i matki, ni krewnych i przyjaciół; oni go tylko ganią ciągle i utrudniają mu ono przemiłe obcowanie. [...] Miłośnik musi zawistnym okiem patrzeć na majątek kochanka i cieszy się, jeśli ten majątek przepada. Więc i bezżennym, bezdzietnym, bezdomnym, i to jak najdłużej, rad by mieć kochanka; jak najdłużej pragnie sam tylko zrywać owoce, które mu tak smakują ${ }^{80}$.

Filozof zdaje sobie sprawę, że miłość erotyczna jest czasami niebezpieczna, a na pewno nie daje takich gwarancji bezpieczeństwa jak przyjaźń, która z zasady jest jasna i przejrzysta. Miłość erotyczna, w przeciwieństwie do przyjaźni, jest gwałtowna, wybuchowa, szalona (mania). Zasadza się bowiem na nierówności między kochającym a kochanym. Jeżeli takie nierówności pojawiają się czasami również w stosunkach przyjaźni, to w ramach państwa - zauważa Arystoteles - są one równoważone pieniądzem, w stosunkach miłości natomiast są przyczyną licznych narzekań i nieporozumień pomiędzy miłośnikami co do rodzaju miłości, jaką winni się darzyć.

W stosunku miłosnym kochający uskarża się niekiedy (chociaż nie ma w nim może nic miłości godnego), że sam nadmierną miłością pałając, nie jest wzajem kochany; często zaś skarży się kochany, że kochający przedtem wszystko mu obiecywał, obecnie zaś nic nie dotrzymuje ${ }^{81}$.

Nieco dalej Arystoteles zwraca uwagę na różnicę w wyborze przyjaciela i ukochanego. Otóż, podczas gdy przyjaciela wybiera się na podstawie trwałej dyspozycji (hexis, habitus) do pełnienia dobra, to ukochana osoba zostaje uprzywilejowana ze względu na moc uczucia miłości (namiętność). Arystoteles pisze:

78 Etyka nikomachejska, IX, 10, 1171 a 11.

79 Na ten temat więcej w: R. CALDARONE, Eros decostruttore, zwł. rozdział III: Figura, hos eromenon, s. $81-122$.

80 Fajdros, $239 \mathrm{E}-240 \mathrm{~A}$.

81 Etyka nikomachejska, IX, 1, 1164 a 2-6; por. Etyka eudemejska, VII, 3, 1238 b 35-39. 
Miłość jest, jak się zdaje, namiętnością, przyjaźń zaś trwałą dyspozycją; bo przedmiotem umiłowania mogą też być przedmioty martwe, wz a je $m \mathrm{n}$ a jednak miłość [tj. przyjaźń] jest wynikiem wyboru [proairesis], a wybór wynikiem trwałej dyspozycji. Ludzie [dobrzy] życzą dobrze tym, dla których żywią uczucie przyjaźni ze względu na nich samych, idąc za nakazem nie uczucia, lecz trwałej dyspozycji ${ }^{2}$.

Według Stagiryty, bardzo ważną rolę w relacji miłości erotycznej odgrywa zmysł wzroku. Przyjemność, jakiej dostarcza widok umiłowanego, jest źródłem miłości: „Dla zakochanych najmilszą rzeczą jest widok osób kochanych, i widok ten przedkładają nad wszelki inny, ponieważ on to przede wszystkim podtrzymuje i rodzi miłość"83. I jeszcze raz powtarza tę samą myśl, ale tym razem w analogii do przyjaźni: „Życzliwość zdaje się być początkiem przyjaźni, tak jak radość oczu jest początkiem miłości: wszak nikt nie kocha drugiego, jeśli przedtem nie radowała go jego powierzchowność" "84. Zaraz jednak precyzuje, że w miłości ważna jest nie tylko powierzchowność, lecz również cierpienie z powodu nieobecności i pragnienie obecności ukochanego: „Ten, kogo cieszy powierzchowność drugiego, jeszcze go nie kocha, lecz wtedy dopiero, kiedy tęskni za nieobecnym i pragnie jego obecności" ${ }^{55}$.

Trafnie znaczenie przyjaźni (philia) w relacji do miłości (eros) odczytuje Martha Nussbaum, która stwierdza, że Arystoteles „nie kładzie nacisku na intensywne, namiętne pragnienie, lecz na bezinteresowną pomoc, na dzielenie się i na wzajemność; nie uwydatnia aspektu szaleńczego, lecz rzadki rodzaj równowagi i harmonii" ${ }^{6}$. Słowa amerykańskiej filozofki i badaczki myśli Stagiryty wydają się odpowiednim podsumowaniem dotychczasowych rozważań nad fenomenem przyjaźni w jego rozumieniu.

\subsubsection{Przyjaźn a mitość w ujęciu św. Teresy od Jezusa}

Św. Teresa, mówiąc o miłości i przyjaźni, operuje zasadniczo dwoma hiszpańskimi słowami: amor (miłość) i amistad (przyjaźń). Nie są one jednak odpowiednikami greckich eros i philia, których wzajemne relacje u Arystotelesa wyżej rozpatrywaliśmy. W myśli Teresy, i w ogóle w kulturze hiszpańskiej XVI wieku -którą dzieli od czasów wielkiego Stagiryty nie tylko dwadzieścia wieków, ale przede wszystkim ogrom nowych doświadczeń ludzkich i religijnych - terminy te mają zupełnie inny zakres semantyczny i wyrażają odmienną intensywność uczuciową niż ich starożytne greckie odpowiedniki.

\footnotetext{
82 Etyka nikomachejska, VIII, 5, 1157 b 28-31.

83 Tamże, IX, 12, 1171 b 29-31.

84 Tamże, IX, 5, 1167 a 5-7.

85 Tamże, IX, 5, 1167 a $7-9$.

86 M. Nussbaum, La fragilità del bene, s. 639.
} 
W pismach św. Teresy słowo amor jest jednym z najczęściej występujących ( 903 razy), lecz nie zawsze wiadomo, kiedy używa go w znaczeniu greckiego erosa, lub choćby miłości naturalnej, kiedy w znaczeniu przyjaźni ( $p h i l i a$ ), a kiedy jeszcze chrześcijańskiej agape. Trzeba więc wiele uwagi i wysiłku, by uchwycić subtelną myśl Teresy i trafnie zidentyfikować każdy z tych rodzajów miłości. Ponadto brakuje odpowiednich studiów na ten temat. Jeśli bowiem zagadnienia przyjaźni (amistad) i miłości chrześcijańskiej (caridad) zostały stosunkowo szeroko i gruntownie przebadane, przede wszystkim przez teologów, to zagadnienie miłości erotycznej (eros) spotkało się z zainteresowaniem głównie ze strony artystów i ludzi sztuki (wystarczy przywołać słynną rzeźbę Berniniego Ekstaza św. Teresy od Jezusa). Jeszcze psychologowie poświęcili wiele uwagi jej seksualności, zastanawiając się, czy mieściła się ona w granicach wyznaczonej przez nich "normalności” czy też nie ${ }^{87}$, ale to zagadnienie nie dotyczy rozważanego tu tematu. Ciekawym materiałem do studium jej miłości w sensie erosa mogłoby być jedno z jej mniejszych pism, będące swoistym komentarzem do Pieśni nad pieśniami, zatytułowane Podniety mitości Bożej ${ }^{88}$.

Choć tego rodzaju badania mogłyby przynieść wiele interesujących odkryć, tutaj ograniczymy się do kilku tylko ogólnych obserwacji natury filozoficznej. Za punkt wyjścia naszych rozważań przyjmujemy wskazane przez współczesnego autora, C.S. Lewisa, konkretne różnice między miłością w znaczeniu eros a miłością w znaczeniu philia. Zakładamy bowiem, że św. Teresa bez wahania podpisałaby się pod następujacymi jego stwierdzeniami:

Nic nie jest mniej podobne do przyjaźni niż zakochanie. Kochankowie zawsze rozmawiają o swojej miłości, przyjaciele bardzo rzadko o swojej przyjaźni. Kochankowie siedzą zwykle naprzeciwko siebie zaabsorbowani nawzajem swoją obecnością, przyjaciele obok siebie zaabsorbowani wspólnym obiektem zainteresowań. A przede wszystkim Eros (póki jego panowanie trwa) łączy oczywiście tylko dwóch ludzi. Ale ta cyfra nie jest bynajmniej konieczna w przyjaźni, ani najbardziej jej sprzyjająca ${ }^{89}$.

W świetle powyższych rozróżnień, jak i tych dokonanych wcześniej przez Arystotelesa, jaśniejsze staje się to, co św. Teresa mówi na ten sam temat w rozdziałach 4-7 Drogi doskonałości. Wstępnie, i znacznie upraszczając sprawy, a zatem wystawiając się na ryzyko pewnego ich zniekształcenia, możemy powiedzieć, że przedstawiona tam przez nią miłość doskonała w jakiś sposób odpowiada Arystotelesowskiej przyjaźni; wydaje się też, że w chwili zakładania przez nią nowej wspólnoty zakon-

87 Por. T. Alvarez, Amor, w: Diccionario de Santa Teresa. Doctrina e Historia, red. T. Alvarez, Burgos 2006, s. 47.

88 W: Teresa od Jezusa, Dzieła, t. III, Kraków 1987, s. 92-152. Nowy przekład Marty Szafrańskiej-Brandt: Rozważania o Pieśni nad pieśniami, Kraków 2017.

89 C.S. Lewis, Cztery mitości, Warszawa 1983, s. 79-80. 
nej, swoistej analogii greckiej polis, to właśnie przyjaźń stanowi główny przedmiot jej zainteresowania i nauczania. Opisana natomiast w tych samych rozdziałach miłość mniej doskonała, „czuła”, miałaby swój odpowiednik w tym, co Grecy, z Platonem na czele, nazywali erosem ze względu na jej silny związek z cielesną przyjemnością. Wydaje się, że nie budzi ona w Teresie wielkiego zaufania. Takie przynajmniej wrażenie odnosi czytelnik przy pierwszej, powierzchownej jeszcze lekturze jej pism.

Potwierdzeniem tych odczuć mógłby być fakt, że to właśnie przyjaźn Ś więta nazywa „dobrą i prawdziwą miłością" (bueno y verdadero amor) (Dv 7, 8). Co więcej, stawia ją naprzeciw miłości mniej doskonałej i mówi wprost:

Lepsza będzie taka przyjaźń [ mejor amistad] niż wszelkie czułości [ternuras] i słowa pieszczotliwe, które choć powszechnie przyjęte na świecie, tu w tym domu naszym nie są w użyciu i nigdy być nie powinny, jak to: „moje serce”, „moje życie”, „mój skarbie”, i inne tym podobne (tamże).

Surowa wypowiedź św. Teresy może wprawić w zdumienie, a nawet zakłopotanie. Nieuprzedzony czytelnik z pewnością zapyta, dlaczego jest tak bezwzględna i zabrania używania słów niosących ładunek czułości. Czy nie zmierza w ten sposób do radykalnego oddzielenia owych dwóch rodzajów miłości, doskonałej ( philia) i mniej doskonałej (eros), przesadnie uprzywilejowując pierwszą z niekorzyścią dla drugiej? Czy w praktyce nie dąży do stłumienia miłości erotycznej, jako zbytnio związanej z cielesnością, całkowitego wyeliminowania jej z życia założonych przez siebie wspólnot i tym samym okaleczenia człowieczeństwa osób, które zawierzyły jej słowu? Czy proponowana przez nią wizja przyjaźni nie jest zbyt duchowa, anielska, a zatem wystawiająca jej adeptów na to największe niebezpieczeństwo, jakie według cytowanego wyżej Lewisa - grozi przyjaźni, a mianowicie na grzech pychy? ${ }^{90}$

Teresa sama przychodzi z pomocą i zaraz w następnym zdaniu nie tylko odpowiada na te wątpliwości, usuwając najstraszliwsze podejrzenia o ideowe deformacje swoich sióstr w klasztorze i niszczenie ich człowieczeństwa, ale zdaje się odsłaniać powoli swoją realistyczną i niezwylle stymulującą myśl również w kwestii erosa. Jej perspektywa jest oczywiście perspektywą wiary:

Czułości takie zachowujcie do rozmowy z waszym Oblubieńcem [Esposo], z którym tyle razy na dzień, w zupełnej samotności [a solas, sam na sam], dano wam jest obcować. Tak mogą one być potrzebne i z pożytkiem możecie ich używać, skoro Jego Boski Majestat raczy je łaskawie przyjmować; a gdyby tutaj były one nadużywane [pospolitowane], straciłyby swą świeżość i siłę i już by wam tak skutecznie serca nie rozgrzewały na rozmowie $z$ Bogiem $(\mathrm{Dv} 7,8)$.

90 Tamże, s. 112: „Pycha jest niebezpieczeństwem z natury rzeczy najbardziej zagrażającym przyjaźni. Ponieważ to najbardziej duchowa z miłości, zagrażające jej niebezpieczeństwo jest również natury duchowej". 
Z powyższego wynika, że Święta absolutnie nie tłumi miłości erotycznej w życiu swoich sióstr w klasztorze i nie wyklucza jej z ich powszedniego języka, a jedynie strzeże jej właściwego znaczenia i zabiega, by była ona zawsze ukierunkowana zgodnie ze swą naturą, to znaczy - na Jedynego, w tym wypadku Boga.

To stanowisko Teresy wyraźnie można zobaczyć na przykładzie jej troski o samo tn ość. Już Platon i Arystoteles, jak zostało to przestawione wcześniej, wskazywali na nia jako na najbardziej charakterystyczny rys miłości erotycznej. Pierwszy z nich, bardziej w niej doświadczony i znacznie śmielszy w mówieniu o niej prawdy do końca, nie waha się wyakcentować nawet dramatycznych skutków maniakalnego dążenia erosa do samotności. Drugi też ma tego wszystkiego świadomość, lecz może z lęku przed owymi skutkami ogranicza się do ogólnego stwierdzenia, że „brak przyjaźni i samotność to rzeczy bardzo straszne" ${ }^{\prime 1}$. C.S. Lewis z kolei ma na uwadze obie te perspektywy i mówi: „Kochankowie szukają odosobnienia. Przyjaciele, czy chca tego czy nie, napotykają wokół siebie samotność, ową barierę wznoszącą się między nimi i stadem ludzkim" 22 .

Św. Teresa nie boi się mówić o samotności - i to zawsze pozytywnie. Samotność jest dla niej czymś uparcie poszukiwanym (zgodnie z dynamiką miłości erotycznej), a nie zaledwie znoszonym (jak w przypadku przyjaźni). Ta „przyjaciółka przyjaciół”, jak często sama o sobie mówiła, jednocześnie otwarcie przyznaje: „moją naturalną skłonnością zawsze była samotność" ${ }^{33}$. Jej zdolność do wchodzenia w relacje i zamiłowanie do komunikowania się z wieloma przyjaciółmi nie zakłócają jej naturalnego dążenia do samotności: „Zostawać samej, choćby najdłużej, nigdy mi się nie sprzykrzy" - wyznaje w Sprawozdaniu duchowym $(1,7)$.

„Jeśli samotność i przyjaźń stanowią dwa podstawowe składniki jej psychiki, to w jej przekonaniu - zauważa o. Tomasz Alvarez, jeden ze znawców jej życia i doktryny - górę bierze pierwszy. Na niej [ samotności] opiera się i rozwija całe jej życie kontemplacyjne i na jej podstawie opracowuje ona swoją pedagogikę modlitwy" ${ }^{\text {". }}$. Definiując modlitwę jako „przyjaźń z Bogiem”, Teresa włącza w to określenie, jako element najbardziej charakterystyczny, oczywiście samotność. Modlitwa według niej to "przyjacielskie z Bogiem obcowanie... sam na sam [tratar de amistad... a solas]" $(\dot{Z}$ 8, 5). Początkującym w modlitwie zaleca „powściągać się od widzenia i słyszenia rzeczy zewnętrznych, usuwając się na samotność” (Ż 11,9). Kiedy natomiast ktoś ma już w sobie Ducha Bożego (miłość), wówczas sam „z pożądaniem wygląda chwili samotności, aby lepiej mógł cieszyć się tym skarbem, tą miłością swoją" (Z 15,14$)$.

Interesującą jest rzeczą, że nawet w rozdziałach 4-7 Drogi doskonatości, a więc w tekście w całości poświęconym miłości przyjaźni, relacjom siostrzanym, „miło-

91 Etyka eudemejska, VII, 1, 1234 b $32 \mathrm{n}$.

92 C.S. Lewis, Cztery mitości, s. 85.

93 List 75, do Antoniego Gaytán w Albie, ostatnie miesiące 1574, n. 2.

94 T. Alvarez, Solitudine, w: Diccionario de Santa Teresa, s. 539. 
ści wzajemnej między nami" (Dv, 4, 5), Teresa nie omieszka mówić o samotności. Przedstawia ją jako wielką wartość i gorąco poleca siostrom. Leży jej bowiem na sercu, jak nic innego, miłość erotyczna. Chce spotęgować jej moc. Mówi zatem, jak choćby w przytoczonym już wyżej zdaniu, o „zupełnej samotności” (a solas, sam na sam) (Dv 7,8), w której miłość i wszystkie jej „czułe” wyrazy skierowane są na Jedynego. "Samotność niezrównanym jest dobrodziejstwem i pomocą" (Dv 4, 9). Podobnie zresztą ma się sprawa z „zachowaniem milc ze n ia, do którego łatwiej przywyknąć, gdy każda zostaje sama u siebie [se guarda el silencio cada una por sí]" (tamże). Jedno i drugie, samotność i milczenie, służy spotkaniu i rozmowie z Jedynym, to znaczy „modlitwie, która ma być spójnią i cementem tego domu” (tamźe).

Temu samemu ma służyć też u nikanie roz proszeń, które tejże samotności są zaprzeczeniem. Chodzi o unikanie wszelkich niewłaściwych spojrzeń i przede wszystkim „ustronnych związków” (Dv 4,9), które odwodzą myśl i uczucia od Jedynego, odciągają dusze „od całkowitego oddania się miłości Bożej” (Dv 4, 5), wygaszają ich miłość, sprawiają, że już nie umieją się rozczulić, dosłownie „nie wzruszaja się" w obecności Jedynego (no enternecen tanto con el Señor) (Dv 7, 8). Z powodu braku samotności duszy zaczyna brakować głębi, rzeczywistość zostaje spłaszczona, a relacje międzyludzkie się pospolitują.

Trzeba powiedzieć, że św. Teresa inaczej niż Arystoteles rozkłada akcenty pomiędzy miłością erotyczną i miłością przyjaźni. Choć ceni tę ostatnią i wychwala ją jako „dobrą i prawdziwą miłośc” [ bueno y verdadero amor] (Dv 7,8), a nawet uważa, że „lepsza jest taka przyjaźń [mejor amistad] niż wszelkie czułości [ternuras] i słowa pieszczotliwe" (tamże), to jednak dla jej gorącego serca jest ona nazbyt rozsądna i zrównoważona. Owszem, Swięta widzi, że przyjaźń zaprowadza harmonię w duszy ludzkiej, zapewnia warunki do kontemplacji piękna, dobra i prawdy, jest też gwarantem umiaru iładu we wspólnocie, ale jednoczenie zdaje sobie sprawę, że nazbyt często wprowadza ona w stan samozadowolenia i uśpienia. Teresa tymczasem cały czas jest w ruchu. Jej eros nie znajduje ukojenia i nie daje się niczym obłaskawić, a już absolutnie niczemu i nikomu nie daje się skrępować. W przeciwieństwie do przyjaźni, nie znosi nawet towarzystwa innych. Jest zazdrosny, zaborczy. Jest szalony. Nie potrafi spocząć, dopóki nie osiągnie celu swoich pożądań, to znaczy dopóki nie zdobędzie Umiłowanego. W chwili natomiast, gdy na jego horyzoncie pojawia się Jedyny, ów Pierwszy Przyjaciel, który stanowi wzór ${ }^{95}$ dla wszystkich innych związków

95 W słynnym traktacie o przyjaźni duchowej Elred z Rievaulx zwraca uwagę na rolę tego rodzaju normy. Przyznaje, że w młodości, „nie znając prawa, które kieruje prawdziwą przyjaźnią”, miotał się pomiędzy „różnego rodzaju miłościami i przyjaźniami” i dawał się zwieść „podobnym do niej uczuciem". Później, z chwilą spotkania Chrystusa, jego perspektywa widzenia i przeżywania rzeczy zupełnie się zmieniła. Od tej bowiem pory „nic, co nie byłoby osłodzone miodem najsłodszego imienia Jezus i przyprawione solą Pisma świętego, nie przyciągało zupełnie mojego uczucia”. ElRed z RievaulX, Przyjaźñ duchowa, Kęty 2003, s. 15-16. 
przyjaźni, wówczas zmienia perspektywę widzenia i ocenę całej rzeczywistości: wszystko, co do tej pory było uładzone, nagle pod jego wpływem ulega wywróceniu.

Platon uważał, że tego rodzaju namiętność miłosna jest swoistą chorobą, na którą każdy może zapaść. Był jednak przekonany, że trzeba się z niej leczyć, gdyż może się okazać bardzo groźna. I choć nie wiadomo, czy robił to zupełnie na poważnie, czy też z nutą ironii, niemniej przestrzegał i wzywał do realizmu:

Więc któż widział, wdawać się w coś podobnego z ludźmi cierpiącymi wadę tego rodzaju, że nie brałby się do jej leczenia nikt, kto ma doświadczenie w tych sprawach? Przecież sami przyznają, że stan ich to choroba raczej niźli zdrowe zmysły, i choć wiedzą, że u nich w głowie źle, nie umieją zapanować nad sobąa.

Św. Teresa w swoim „szaleństwie” idzie dalej. Owszem, ona również ma świadomość, że miłość erotyczna to „choroba”. Inaczej jednak niż Platon, diagnozujący innych, wie, że ta choroba dotyka jej samej. Co więcej, absolutnie nie chce się z niej leczyć. Przeciwnie, chce czegoś naprawdę szalonego. W Księdze życia, zwracając się do swego przyjaciela o. Garcii de Toledo, pisze bez ogródek:

Chciałabym widzieć wkoło siebie samych tylko chorych na tę samą chorobę, którą ja w tej chwili jestem dotknięta. Błagam miłości waszej, bądźmy wszyscy szaleni dla miłości Tego, który dla nas dopuścił, aby Go miano za szalonego. Mówisz wasza miłość, że mię kochasz, więc okaż mi tę miłość swoją, czyniąc siebie sposobnym, aby i tobie Bóg tej łaski użyczył. Bo bardzo mało widzę takich, którzy by nie powodowali się zbytnim rozsądkiem $w$ tym, co by ich mogło doskonalszymi uczynić $(\dot{Z} 16,6)$.

Bóg jest dla Teresy bardziej realny niż wszelka realność zewnętrznego świata. Nic więc dziwnego, że pragnie nawiązać z Nim relację nie tylko duchową, ale także cielesną. W tej relacji jest On dla niej nie tylko Przyjacielem, z którym prowadzi poufną rozmowę/modlitwę, dzieląc podobne idee i zapatrywania, ale przede wszystkim jest Umiłowanym/Oblubieńcem, którego pragnie posiąść cieleśnie i któremu również cieleśnie chce oddać całą siebie - ze wszystkimi swymi uczuciami/namiętnościami, każdym drgnieniem swego kochającego serca. Teresa nie poprzestaje w tej relacji na poziomie wolnych myśli i słów i nie zadowala się samą tylko duchową zgodą, harmonią, jednością - ona dąży do faktycznego zjednoczenia. Jeśli na poziomie duchowych myśli ta jej przyjacielsko-miłosna relacja z Bogiem jest jasna i przejrzysta, a oblicze Boga świetlane, to na poziomie ciał wszystko zostaje zanurzone w ciemnościach niezwykle głębokiej tajemnicy, która od obu partnerów wymaga absolutnej pokory - otchłań bowiem, jaka dzieli ciała, odczuwana jest jako nieznośna separacja,

96 Fajdros, $231 \mathrm{C}-\mathrm{D}$. 
którą po prostu trzeba wycierpieć. Jest to niewątpliwie ów krytyczny punkt - ta konieczność pokornego cierpienia! - o który rozbija się większość przyjaźni, a w którym eros, nieznający żadnych przeszkód, doskonale sobie radzi.

Skupienie Teresy na miłości erotycznej ukierunkowanej na Jedynego Oblubieńca i jednoczesne uduchowienie przez nią przyjaźni nie oznacza bynajmniej rozpuszczenia tej ostatniej w miłości Boga. Przyjaźń cały czas zachowuje swój niezależny od erosa kształt - i to zarówno w wymiarze horyzontalnym, jak i wertykalnym, w relacjach międzyludzkich i w relacji do Boga. Trzeba jednak przyznać, że jeżeli początkowo w życiu Teresy górę bierze przyjaźn - dokładniej: przyjaźnie międzyludzkie, które mimo wszystkich swych ograniczeń pozwalają jej idealistycznie myśleć o podobnej przyjaźni w relacji z Bogiem - to w miarę upływu czasu i zrozumienia praw życia duchowego coraz bardziej daje o sobie znać radykalna/szaleńcza/otwarta na nieskończoność miłość erotyczna. To ona dynamizuje jej życie. Niemniej jednak i ona nie jest czymś ostatecznym.

Spoza niej bowiem, czyli spoza jej rozpalonej miłością duszy - jak określa to sama Teresa w ostatnim, czterdziestym rozdziale Ksiegi życia - pewnego dnia objawia się prawda o przyjaźni, która nie tylko przekracza jej dziecięce i młodzieńcze wyobrażenia opisane w pierwszych dziesięciu rozdziałach tej autobiografii, ale ,jest dopetnieniem wszystkich prawd" i ,jedną z największych łask”, jakie otrzymała od Jezusa $(\dot{Z} 40,1)^{97}$. Teresa słyszy mianowicie słowa swego boskiego Oblubieńca i Przyjaciela, nawiązujące wprost do słów, które wypowiedział do uczniów podczas Ostatniej Wieczerzy, a które bez wątpienia są szczytem objawienia prawdy o przyjaźni w Nowym Testamencie: „uż was nie nazywam sługami, bo sługa nie wie, co czyni pan jego, ale nazwałem was przyjaciółmi, albowiem oznajmiłem wam wszystko, co usłyszałem od Ojca mego" (J 15, 15). Słowa wypowiedziane do niej są wyrazem tego samego przyjacielskiego zaufania, jakie okazał uczniom, ale zawierają też coś nowego, mianowicie potężny ładunek bólu, jakim boski Przyjaciel dzieli się ze swą przyjaciółką - i tylko z nią:

O córko ${ }^{98}$, jak mało jest takich, którzy by Mię kochali w prawdzie! Gdyby Mię kochali, nie ukrywałbym przed nimi tajemnic swoich. Czy wiesz, co to znaczy kochać Mię w prawdzie? Znaczy to: rozumieć, że wszystko, cokolwiek Mnie się nie

97 Por. T. Álvarez, Komentarz do Księgi życia świętej Teresy od Jezusa, Kraków 2009, s. 270-273.

98 Należy zauważyć, że Teresa, w przeciwieństwie np. do św. Jana od Krzyża, nigdy, dosłownie nigdy nie zwraca się do Boga przez "Ty” - nawet w najbardziej zażylych i najczulszych doświadczeniach przyjaźni na modlitwie, w chwilach największej wewnętrznej swobody. Bóg jest dla niej zawsze „Waszym Majestatem”, „Waszą Wielmożnością" itd. Podobnie w drugą stronę (jak widzimy w tym wypadku): Bóg nie mówi do Teresy „przyjaciółko”, ale „córko”. Niezależnie od zewnętrznych form językowych, które zawsze są kulturowo uwarunkowane, dla nas istotna pozostaje treść i wewnętrzna tonacja całej wypowiedzi. 
podoba, jest kłamstwem. Prawdy tej jeszcze nie rozumiesz, ale zrozumiesz, gdy ujrzysz, jaką z niej dusza twoja korzyść odniesie (Ż 40,1).

Znajdujemy się tu niewątpliwie na styku filozofii i teologii, a więc także w otwartości na wymiar nadprzyrodzony i jego dobroczynne oddziaływanie na ludzki rozum ${ }^{99}$. Słowo objawienia dane Teresie należy w pierwszym rzędzie do porządku teologiiteologii chrześcijańskiej. Nie jest jakimkolwiek słowem, lecz „Słowem, które stało się ciałem". Słowo Boga rozumiane jako Syn Boży, czyli druga Osoba Trójcy Przenajświętszej, przybrało postać, która pozwoliła Bogu wyrazić się nie tyle przez intelektualne spekulacje, ile poprzez „oddanie swojego ciała” (ciało bowiem jako takie nie mówi). W objawieniu skierowanym do Teresy - jak to jednoznacznie wynika z wyżej przytoczonego tekstu - Bóg wyraził gotowość, a nawet pragnienie odsłonięcia przed ludźmi wszystkich „swoich tajemnic”. Ale ma On też powody do dalszego ich ukrywania. Choć w pierwszym momencie mogą nam się one wydać nieco zaskakujące, są niebanalne, a leżą wyłącznie po stronie ludzi: „wszelkie szkody i nieszczęścia, jakie przychodzą na świat, powstają stąa, że ludzie nie znają jasno i nieobłudnie prawd Pisma Świętego: a przecież nie ma w nim jednej joty, która by się nie spełniła" $(\dot{Z} 40,1)$. Współczesny czytelnik, przyzwyczajony do myślenia o poznawaniu wyłącznie w kategoriach intelektualnych i teoretycznych, w sensie zdolności zapanowania nad tekstem, łatwo może ulec mniemaniu, że nie ma większych problemów ze znajomością Pisma Świętego. Podobnemu zresztą złudzeniu ulegała sama św. Teresa, której „zdawało się, że zawsze w Pismo Święte wierzyła, i że wszyscy wierni czynią podobnie" (tamże). Tymczasem chodzi tutaj o coś znacznie głębszego niż tylko o teoretyczną znajomość słowa Bożego czy powierzchowną wiarę. Chodzi o egzystencjalne i osobowe uznanie, że ze strony Boga każda jota rzeczywiście się spełniła, to znaczy „Słowo stało się ciałem" i przez cielesne oddanie się (krzyż i Eucharystia) Bóg wyraził już swoją pełną miłość do ludzi - ludziom natomiast brakuje podobnej miłości do Boga i dlatego z ich strony nie dochodzi do cielesnego dopełnienia tej relacji. Najbardziej cierpi z tego powodu sam Bóg, ponieważ nie może zrealizować swojego najgłębszego pragnienia, czyli przyjaźni z ludźmi: „Gdyby Mię kochali, nie ukrywałbym przed nimi tajemnic swoich" (tamże).

To samo słowo mistycznego objawienia należy również do porząadku filozoficznego i także w tym obszarze ma wiele do powiedzenia. Przede wszystkim jest słowem przyjacielskim i jako takie chce pomóc Teresie w dojściu do pełnej prawdy o miłości osobowej. Toteż nie chce ono negować jej rozumu, ale zmierza do zdynamizowania jego potencjału i poszerzenia jego horyzontów poprzez wejście w twórczy, osobowy

99 Por. Jan Pawee II, Encyklika Fides et ratio do biskupów Kościoła katolickiego o relacjach między wiarą a rozumem, Kraków 1998, rozdział Wzajemne oddzialywanie teologii i filozofii, nn. 64-79. Por. także I. BIFF, Il senso teologico della filosofia e la liberazione della ragione, Roma 2015; E. FALQuE, La grande traversata. Filosofia e teologia, Roma 2017. 
dialog z Teresą (człowiekiem): „Czy wiesz, co to znaczy kochać Mię w prawdzie?” (tamże). Pytanie Pierwszego Przyjaciela ma wymiar intelektualny, jest pytaniem o wiedzę, ale dotyczy miłości ( „kochać”) - tej samej miłości, o której była mowa wyżej, w „porządku teologicznym”. Jeżeli jednak tam uwydatnił On głównie brak miłości (w znaczeniu erosa) u innych, a chodziło $M u$ po prostu o jej wzbudzenie poprzez odwołanie się do potencjału Pisma Swiętego i wiary ludzi, to tutaj zwraca się bezpośrednio do samej Teresy. Wybiera ją w ten sposób spośród wielu i wchodzi z nią w relację przyjaźni. W konkrecie natomiast przystępuje do wybadania potencjału jej władz duchowych, w szczególności poznawczych. Nie jakoby nic nie wiedział na ten temat, ale żeby poprzez przyjacielskie pytanie przygotować w jej duszy „grunt” dla zakomunikowania prawdy, która inaczej mogłaby okazać się zbyt trudna do przyjęcia dla jej rozumu. Sam ją ostatecznie komunikuje i tym samym odpowiada na postawione przez siebie pytanie: „Znaczy to: rozumieć, że wszystko, cokolwiek Mnie się nie podoba, jest kłamstwem" (tamże). Miłośnik prawdy nie przekazuje Teresie jakiejś rozpowszechnionej opinii na temat miłości, na przykład miłości w sensie doznawania uczuć, ale dzieli się samą prawdą o niej - prawdą, która jako taka ma charakter absolutny. Żaden z ziemskich przyjaciół nie mógłby w taki sposób („cokolwiek Mnie się nie podoba, jest kłamstwem") przekazać przyjacielowi prawdy o swojej miłości. Może to uczynić tylko Bóg, który jest Prawdą i który dał świadectwo mi łości absolutnej, oddając życie za przyjaciół nie pod wpływem jakiegoś ślepego impulsu cielesnego, lecz w świadomej relacji osobowej. Przyjęcie tej prawdy przez człowieka, jej zrozumienie i odwzajemnienie jest moźliwe jedynie w podobnej miłości-czyli w przyjaźni. W Teresie jest ona wprawdzie ogromna, ale nie na tyle mocna, by jej rozum nie doświadczał jeszcze pewnych trudności. Dostrzega je oczywiście Pierwszy Przyjaciel, który przychodzi jej w sukurs i otwiera przed nią zaskakującą perspektywę filozoficzną: „Prawdy tej jeszcze nie rozumiesz, ale zrozumiesz, gdy ujrzysz, jaką z niej dusza twoja korzyść odniesie" (tamże). Bóg jako Prawda absolutna nie podaje Teresie jakiegoś abstrakcyjnego kryterium, za pomocą którego mogłaby ona tylko z trudem rozpoznać Ją w codziennym życiu, lecz praktyczne. Jest nim „korzyść", jaką odnosi jej dusza w relacji z Pierwszym Przyjacielem! Tak oto przyjaźń objawiona Teresie podana jest jej na sposób grecki: będąc czymś pięknym, szlachetnym i zachwycającym, jest zarazem czymś dobrym, to znaczy - właśnie w greckim tego słowa znaczeniu - korzystnym. Albo inaczej: przyjaźń ukazana jako kalokagatia, czyli zarówno piękno, jak i dobro, jednocześnie zachwyca i leży w naszym prawdziwym interesie ${ }^{100}$.

100 „Język grecki czasów Platona dysponował dwoma różnymi określeniami dobra: po pierwsze w znaczeniu tego, co korzystne, opłacalne, aby doń dążyć; po wtóre w znaczeniu tego, co moralnie dobre. Do pierwszego odnosi się określenie agathón - dobro, do drugiego kalón - piękno. [...] Intencją Platona jest pokazanie, że to, co piękne, jest zarazem - i to nie $z$ jakichś zewnętrznych racji, lecz jako takie - 'dobre', to znaczy leży w naszym prawdziwym interesie, co więcej, wyznacza nasz prawdziwy interes". R. Spaemann, Szczęście a życzliwość, s. 16. Por. W. Tatarkiewicz, 
Całość tych teologiczno-filozoficznych rozważań nawiązujących do mistycznego objawienia prawdy o miłości/przyjaźni, które było udziałem św. Teresy, możemy podsumować następująco: jeżeli w porządku teologicznym górę brał bosko-ludzki eros, który gwarantował życiową jedność słowa i ciała, albo syntezę słowa i wiary, to w porządku filozoficznym górę bierze philia, która z kolei gwarantuje egzystencjalną jedność trzech transcendentaliów: prawdy, piękna i dobra. Obydwa porządki wzajemnie się potrzebują, dopełniają i otwierają na najgłębszą prawdę miłości/przyjaźni.

\section{ZAKOŃCZENIE}

Wielcy przyjaciele prawdy łatwo się rozpoznają, nawet gdy dzieli ich znaczna odległość kultur i języków. Mowa tu oczywiście o dwóch bohaterach dialogu na temat filozofii przyjaźni, Arystotelesie i św. Teresie od Jezusa. Głównie jednak o tej ostatniej, gdyż żyła znacznie później, zatem celem niniejszej pracy było wykazanie, na ile etyczna nauka Stagiryty jest bliska hiszpańskiej Świętej i czy nie ma ona jakichś uzasadnionych trudności z odnalezieniem się w jego koncepcji przyjaźni. Trzeba przyznać, że nie tylko nie miała żadnych kompleksów wobec wielkiego Greka, ale ze swobodą, a nadto $z$ wielkim kobiecym wdziękiem prowadziła $z$ nim równorzędny dialog na tematy, które - warto to podkreślić - zwykle wymagają wielu lat pogłębionych studiów i mimo to (jak wszystkie tematy ludzkie) pozostają wciąż zawiłe.

Teresa mówiła z własnego doświadczenia. To czyniło jej naukę świeżą, naturalną, przekonującą, prostą i ostatecznie bliską wrażliwości każdego człowieka, niezależnie od czasu, miejsca, kultury czy wyznawanej religii. Pozostawała ona otwarta na każdego, kto tylko żywił pragnienie prawdy i - tak jak Święta - chciał być przyjacielem mądrości (filo-sophia).

Wielkim sprzymierzeńcem jej wyważonych sądów i jasności wypowiedzi były okoliczności kulturowe czasów, w których żyła ${ }^{101}$. Chodzi tu o powszechny i wręcz entuzjastyczny powrót do starożytności i źródeł myśli klasycznej w dobie renesansu. Wiek XVI jest de facto „punktem szczytowym” 102 w recepcji spuścizny filozoficznej Arystotelesa w Europie Zachodniej, a ośrodki hiszpańskie, takie jak Salamanka czy Toledo, w których często przebywa Teresa, odgrywają pierwszorzędną rolę w działalności translatorskiej i komentatorskiej jego pism, w tym również Etyk. Arystotelizm jest dyskutowany na filozoficznych salonach, w dialogu otwartym na wszystkich. Teresa, dzięki licznym przyjaźniom z najbardziej wykształconymi ludźmi swojej epo-

O bezwzględności dobra, w: tenże, Dobro i oczywistość, s. 25-103, szczególnie ostatni rozdział: Teoria regut wzgled dnych, s. 93-103.

101 Zob. część pierwszą niniejszego opracowania, „Itinera Spiritualia” IX (2016), punkt 1.3, s. 114 -117 (przyp. red.).

102 Por. D. Gromska, Wstep Ttumacza, w: Arystoteles, Dzieła wszystkie, t. V, Warszawa 2000, s. 17. 
ki (letrados), chłonie przekazywaną jej z najwyższych sfer samą istotę intelektualnej mądrości i robi z niej najlepszy użytek.

Zasadniczo zgadza się z Arystotelesowską koncepcją przyjaźni. Ma się nawet nieodparte wrażenie, że najbardziej podstawowe elementy strukturalne jego wizji, po naniesieniu nieznacznych korekt, przyjmuje jako podstawę w tworzeniu własnej konstrukcji, którą odważnie proponuje siostrom w założonych przez siebie klasztorach. Wydaje się, że Arystoteles i Teresa w większości kwestii mówią prawie jednym głosem. Ta zgodność dotyczy takich aspektów przyjaźni, jak:

- ukierunkowanie na dobro, które stanowi główny motor napędowy wszystkich duchowych sił w człowieku;

- potrzeba przyjaźni, która jest potrzebą każdego, kto chce lepiej poznać samego siebie i żyć bardziej po ludzku;

- warunki i cechy przyjaźni, których w żadnym wypadku nie należy pomijać podczas zawiązywania właściwej relacji;

- formy przyjaźni, które pozwalają odróżnić przyjaźń prawdziwą od przyjaźni tylko przez analogię;

- rozumienie przyjaźni jako cnoty, bezktórej trudnow ogóle mówić o przyjaźni prawdziwej, bezinteresownej i trwałej;

- rozumienie przyjaźni jako uczucia, które towarzyszy każdej przyjaźni, a nie zawsze łatwo rozpoznać jego autentyczność.

$Z$ powyższego wyliczenia płynie przede wszystkim potwierdzenie faktu, że klasyczna, Arystotelesowska wizja przyjaźni, która jeszcze w czasach św. Teresy była bardzo żywa, dzisiaj w znacznym stopniu uległa zapomnieniu, chociaż nadal zasługuje na wielką uwagę. Niestety, $z$ wymienionych cech przyjaźni, które dla Arystotelesa i Teresy stanowiły podstawę autentycznego spotkania duchowego, do współczesności dotrwał tylko ostatni element - uczucie - i to jeszcze w wydaniu wyłącznie biologicznym (emocji, doznań).

Trzeba jednak zauważyć, że św. Teresa nie tylko zgadza się z Arystotelesem w jego wizji przyjaźni, przyjmując jej podstawowe elementy strukturalne jako własne, ale pozwala sobie również na korektę tej wizji w niek tórych punktach, a nawet na zajęcie zupełnie odrębnego stanowiska. Dotyczy to przede wszystkim kwestii mo żliw ości przyjaźni z Bogiem. Teresa wyprowadza przyjaźń z ciasnej immanencji, w jakiej zamknął ją Arystoteles, i otwiera ją na nieskończoność. Ta zasadnicza różnica naprowadza natychmiast na kolejną, a mianowicie na inną wartość, jaką oboje przyznają miłości przyjaźni i miłości erotycznej.

Interesującą jest rzeczą, że akurat te dwie kwestie - przyjaźń z Bogiem oraz miłość erotyczna - ściśle ze sobą połączone poprowadziły Teresę ścieżkami zupełnie odmiennymi od tych, którymi kroczył Arystoteles. Odnosi się nieodparte wrażenie, że stało się tak dlatego, iż po prostu obie „wymknęły się” myślicielowi-racjonaliście. Trzeba dodać, że „wymykają się” również całej kulturze nowożytnej. Tymczasem to 
właśnie one wydają się stanowić najbardziej obiecujący punkt wyjścia do od nowy międzyludzkich przyjaźni. Są to jednak zagadnienia, które domagają się odrębnego rozwinięcia.

\section{BIBLIOGRAFIA}

Arystoteles, Etyka nikomachejska. Etyka wielka. Etyka eudemejska, w: tenże, Dzieła wszystkie, t. V, Warszawa 2000.

Platon, Dialogi, t. I-II, Kęty 1999.

Teresa od Jezusa, Droga doskonałości, w: taż, Dzieła, t. II, Kraków 1987, s. 5-217.

Alvarez T., Amigos. Amistad. Amor, w: Diccionario de Santa Teresa. Doctrina e Historia, red. T. Alvarez, Burgos 2006, s. 38-49.

Caldarone R., Eros decostruttore. Metafisica e desiderio in Aristotele, Genova 2001.

Danani C., L'amicizia degli antichi. Gadamer in dialogo con Platone e Aristotele, Milano 2003.

Fermani A., L'etica di Aristotele. Il mondo della vita umana, Brescia 2012.

Gadamer H.-G., Idea dobra w dyskusji między Platonem i Arystotelesem, Kęty 2002.

Gadamer H.-G., Przyjaźn i poznanie siebie. O roli przyjaźni wo greckiej etyce, w: tenże, Teoria, etyka edukacja. Eseje wybrane, Warszawa 2008, s. 143-156.

Herer M., Pochwata przyjaźni, Warszawa 2017.

Janusiewicz W., La sapienza è amicizia nella Summa Theologica di Tommaso d'Aquino, Roma 2012.

Lewis C.S., Przyjaźn, w: tenże, Cztery mitości, Printed in Poland 1983, s. 75-116.

MASPERo G., Dell'amicizia con Dio nel pensiero greco: paradosso e paradigma dell'amore tra filosofia e teologia, w: Philia. Riflessioni sull amicizia, red. M. D'Avenia, A. Acerbi, Roma 2007, s. 273-279.

Nussbaum M., Terapia del desiderio. Teoria e pratica nell' etica ellenistica, Milano 1998.

Nussbaum M., La fragilità del bene. Fortuna ed etica nella tragedia e nella filosofia greca, Bologna 2016.

Pellegrini G., Il bene e l'apparenza. Aristotele, l'amicizia e i limiti della morale, Roma 2008.

Smolak M., Przyjaźń w świetle etyki Arystotelesa, Kraków 2013.

Spaemann R., Szczéście a życzliwość. Esej o etyce, Lublin 1997.

Tatarkiewicz W., Trzy etyki: studium z Arystotelesa, w: tenże, Dobro i oczywistość, Lublin 1989, s. 209-225.

VANIER J., Il sapore della felicità. Alle basi della morale con Aristotele, Bologna 2001. 


\section{ABSTRACT \\ Albert Staniseaw Wach OCD \\ Toward the Philosophy of Friendship. \\ In Dialogue with Plato, Aristotle and St Teresa (Part III)}

The article constitutes the third part our study of the philosophy of friendship. It presents a sort of dialogue between three great experts in this field: Plato, Aristotle and St Teresa of Avila. They gave testimony to the central place of the idea of friendship in their respective times, and they help modernity to retrieve it.

The first point in the third part of this study takes up again the question of the interpersonal relationships, and, specifically, describes various types of friendship (3.4). St Teresa distinguishes only two types of friendship, whereas Aristotle speaks of three. Their reflections have an existential value in that they help us to distinguish authentic from inauthentic forms of friendship.

The study proceeds by considering friendship as virtue (3.5) and friendship as affection (or passion) (3.6). These two concepts are fundamental for understanding friendship as such. The first (virtue) brings out the ideal significance of friendship. The second (passion) speaks of its significance in reality. These meanings are distinct, but not opposed.

The final point of this study, and the final element in the dialogue between Teresa and Aristotle, picks up again the question of the two related but distinct concepts, namely "friendship" and "love" (3.7). Aristotle and Teresa are in agreement that "friendship" and "love" are not identical: at times they are very close, but at times their meanings are quite distant. Aristotle speaks more of friendship (because of its political significance for the polis); Teresa on the other hand stresses more the significance of love (because of its significance for spousal relationship with God).

In the light of this discussion of the relationship between Aristotle and Teresa, allows us to draw certain conclusions: namely, that their understandings of friendship are very close, but Teresa's vision does not depend on Aristotle's in a slavish way. Teresa, living many centuries after Aristotle, benefits from Aristotle's discoveries but goes beyond them by developing her own position. This Teresian understanding is seen above all in the possibility of friendship with God, and in the erotic significance of love in human life.

Słowa klucze: dobro, przyjaźń, miłość, cnota, uczucie, etyka, przykazanie

Keywords: good, friendship, love, virtue, feeling (affection), ethics, commandment 